\title{
Article \\ Potential Prognostic Biomarkers of NIMA (Never in Mitosis, Gene A)-Related Kinase (NEK) Family Members in Breast Cancer
}

\author{
Gangga Anuraga ${ }^{1,2,3,+} \oplus$, Wei-Jan Wang ${ }^{4,+}$, Nam Nhut Phan ${ }^{5}$, Nu Thuy An Ton ${ }^{5}$, Hoang Dang Khoa Ta ${ }^{1,2} \oplus^{\circ}$, \\ Fidelia Berenice Prayugo ${ }^{2}$, Do Thi Minh Xuan ${ }^{2}$, Su-Chi Ku ${ }^{2}$, Yung-Fu Wu ${ }^{6}$, Vivin Andriani ${ }^{7}$, \\ Muhammad Athoillah ${ }^{3}\left(\mathbb{0}\right.$, Kuen-Haur Lee ${ }^{1,2,8}$ (D) and Chih-Yang Wang ${ }^{1,2, *}$ (i)
}

\section{check for} updates

Citation: Anuraga, G.; Wang, W.-J.; Phan, N.N.; An Ton, N.T.; Ta, H.D.K.; Berenice Prayugo, F.; Minh Xuan, D.T.; Ku, S.-C.; Wu, Y.-F.; Andriani, V.; et al. Potential Prognostic Biomarkers of NIMA (Never in Mitosis, Gene A)-Related Kinase (NEK) Family Members in Breast Cancer. J. Pers. Med. 2021, 11, 1089. https:// doi.org/10.3390/jpm11111089

Academic Editor: Michal Marczyk

Received: 27 September 2021

Accepted: 19 October 2021

Published: 26 October 2021

Publisher's Note: MDPI stays neutral with regard to jurisdictional claims in published maps and institutional affiliations.

Copyright: (C) 2021 by the authors. Licensee MDPI, Basel, Switzerland. This article is an open access article distributed under the terms and conditions of the Creative Commons Attribution (CC BY) license (https:/ / creativecommons.org/licenses/by/ $4.0 /)$.
1 PhD Program for Cancer Molecular Biology and Drug Discovery, College of Medical Science and Technology, Taipei Medical University and Academia Sinica, Taipei 11031, Taiwan; g.anuraga@unipasby.ac.id (G.A.); d621109004@tmu.edu.tw (H.D.K.T.); khlee@tmu.edu.tw (K.-H.L.)

2 Graduate Institute of Cancer Biology and Drug Discovery, College of Medical Science and Technology, Taipei Medical University, Taipei 11031, Taiwan; m142109005@tmu.edu.tw (F.B.P.); m654110001@tmu.edu.tw (D.T.M.X.); b101104152@tmu.edu.tw (S.-C.K.)

3 Department of Statistics, Faculty of Science and Technology, Universitas PGRI Adi Buana, Surabaya 60234, Indonesia; athoillah@unipasby.ac.id

4 Research Center for Cancer Biology, Department of Biological Science and Technology, China Medical University, Taichung 40604, Taiwan; cvcsky@cmu.edu.tw

5 Institute for Environmental Science, Nguyen Tat Thanh University, Ho Chi Minh City 700000, Vietnam; pnnam@ntt.edu.vn (N.N.P.); tntan@ntt.edu.vn (N.T.A.T.)

6 Department of Medical Research, Tri-Service General Hospital, School of Medicine, National Defense Medical Center, Taipei 11490, Taiwan; qrince@yahoo.com.tw

7 Department of Biological Science, Faculty of Science and Technology, Universitas PGRI Adi Buana, Surabaya 60234, Indonesia; v.andriani@unipasby.ac.id

8 Cancer Center, Wan Fang Hospital, Taipei Medical University, Taipei 11031, Taiwan

* Correspondence: chihyang@tmu.edu.tw

+ Equal contributors.

Abstract: Breast cancer remains the most common malignant cancer in women, with a staggering incidence of two million cases annually worldwide; therefore, it is crucial to explore novel biomarkers to assess the diagnosis and prognosis of breast cancer patients. NIMA-related kinase (NEK) protein kinase contains 11 family members named NEK1-NEK11, which were discovered from Aspergillus Nidulans; however, the role of NEK family genes for tumor development remains unclear and requires additional study. In the present study, we investigate the prognosis relationships of NEK family genes for breast cancer development, as well as the gene expression signature via the bioinformatics approach. The results of several integrative analyses revealed that most of the NEK family genes are overexpressed in breast cancer. Among these family genes, NEK2/6/8 overexpression had poor prognostic significance in distant metastasis-free survival (DMFS) in breast cancer patients. Meanwhile, NEK2/6 had the highest level of DNA methylation, and the functional enrichment analysis from MetaCore and Gene Set Enrichment Analysis (GSEA) suggested that NEK2 was associated with the cell cycle, G2M checkpoint, DNA repair, E2F, MYC, MTORC1, and interferon-related signaling. Moreover, Tumor Immune Estimation Resource (TIMER) results showed that the transcriptional levels of NEK2 were positively correlated with immune infiltration of B cells and CD4 ${ }^{+} \mathrm{T}$ Cell. Collectively, the current study indicated that NEK family genes, especially NEK2 which is involved in immune infiltration, and may serve as prognosis biomarkers for breast cancer progression.

Keywords: breast cancer; bioinformatics; biomarker; prognosis; NEK family genes; immune microenvironment; immune infiltration; functional enrichment analysis 


\section{Introduction}

Breast cancer is one of the most common cancers that frequently occurs in women. Moreover, it has become one of the significant causes of death in women throughout the world. According to the most recent global cancer burden report, 2.26 million new breast cancer cases were diagnosed globally [1]. Furthermore, the complexity of breast cancer makes it difficult to fully comprehend its carcinogenesis, progression, invasion, and metastasis using clinical and molecular markers used for early detection [2-6]. Therefore, it is crucial to explore potential novel biomarkers for assessing the diagnosis and prognosis of breast cancer patients [7-12].

NIMA (Never in Mitosis, Gene a)-Related Kinase (NEK) is a family of protein kinases [13]. NEK consists of 11 members of protein kinase, namely NEK1 NEK11 [14,15]. Detailed basic characteristics of the NEK gene family are presented in Table 1.

Table 1. Basic Characteristics of the NEK Genes Family.

\begin{tabular}{ccccc}
\hline $\begin{array}{c}\text { Approved } \\
\text { Symbol }\end{array}$ & HGNC ID & Gene ID & Aliases & $\begin{array}{c}\text { Location on } \\
\text { Chromosome }\end{array}$ \\
\hline NEK1 & 7744 & 4750 & NY-REN-55; KIAA1901 & $4 \mathrm{q} 33$ \\
NEK2 & 7745 & 4751 & NLK1; PPP1R111; RP67 & $1 \mathrm{q} 32.3$ \\
NEK3 & 7746 & 4752 & HSPK36 & $13 \mathrm{q} 14.3$ \\
NEK4 & 11399 & 6787 & Pp12301; NRK2; STK2 & $3 \mathrm{p} 21.1$ \\
NEK5 & 7748 & 341676 & EC 2.7.11.1 & $13 \mathrm{q} 14.3$ \\
NEK6 & 7749 & 10783 & SID6-1512 & $9 \mathrm{q} 33.3$ \\
NEK7 & 13386 & 140609 & EC 2.7.11.1 & $1 \mathrm{q} 31.3$ \\
NEK8 & 13387 & 284086 & NPHP9 & $17 \mathrm{q} 11.2$ \\
NEK9 & 18591 & 91754 & NERCC; DKFZp434D0935 & $14 \mathrm{q} 24.3$ \\
NEK10 & 18592 & 152110 & FLJ32685; CILD44 & $3 \mathrm{p} 24.1$ \\
NEK11 & 18593 & 79858 & FLJ23495; EC 2.7.11.1 & $3 \mathrm{q} 22.1$ \\
\hline
\end{tabular}

The protein kinase family of NEK has been implicated in the development of various cancers [13]. Previous research demonstrated that NEK1 regulated bladder [16], kidney [17], and breast cancer progression [18]. Several NEK genes have also been identified to be linked with breast cancer, such as NEK2 [19] and NEK3 [20] were found to be overexpressed in human breast cancer. MicroRNA (miR)-128-3p inhibits the stem-like cell characteristics of breast cancer stem cells (BCSCs) by inhibiting the Wnt signaling pathway via downregulating NEK2, creating a new target for breast cancer treatment [21]. NEK5 was also linked to breast cancer development and a poor prognosis [22]. NEK7 had high expression in larynx, breast, colorectal [23], and gall bladder cancers [24]. NEK8 is overexpressed in primary breast tumors in humans, and it has considerable sequence similarity to the NEK family of protein kinases and may be involved in $\mathrm{G}_{2} / \mathrm{M}$ development [25].

Various studies looking for novel polymorphisms in carriers of the BRCA type 1/2 susceptibility protein (BRCA1/2) mutation revealed that NEK10 mutations were associated with breast cancer [26,27]. Moreover, NEK10 phosphorylates p53 at Y327, promoting cell cycle arrest after exposure to DNA damaging agents [28]. NEK11 also plays an essential role in cancer development, and is required for survival, regardless of whether cells were exposed to DNA damage [29]. NEKs are associated with several DNA damage response pathways, such as ATM/ATR, CHK1, CDKs, p53/p21, and RAD51 [30]. NEK1 is an ATR activator that causes cell cycle arrest, ensuring DNA repair while also activating particular repair pathways, including homologous repair (HR) and DNA double-strand break (DSB) repair. ATR and ATM were downstream effectors of NEK2, 6, 8, 9, and 11, which results in cell cycle arrest, although the details of possibly active repair pathways are still being explored. Through recruitment of DNA-PK to DNA damage foci, NEK4 is linked to the control of non-homologous end-joining (NHEJ) repair of DNA DSBs [31-36].

Comprehensive analyses of the promising effects of the NEK gene family on breast cancer are lacking in the current stage. Furthermore, analyses with bioinformatics methods have not been widely used to investigate the performance of NEK family members in breast 
cancer. Cell cycle kinases play an essential role in the development of cancer therapy [37]. However, whether these NEK family members can regulate cell cycle kinase procedure is still unclear [38]. Therefore, a complete investigation of various members of the NEK family in breast cancer is needed to explain expression levels, molecular mechanisms, and functional enrichment analyses of breast cancer, which could potentially provide novel prognostic indicators for this complex disease (Figure 1). In this study, we used various large-scale bioinformatics databases to carry out systematic bioinformatics analysis [39-43]. First, we used the tumor immune estimation resource (TIMER) database, Cancer Cell Lines Encyclopedia (CCLE), and UALCAN analysis to determine NEK gene family expression differences between breast cancer and normal tissue. Second, we used Kaplan-Meier plots to reveal the significance of NEK gene family members to the prognosis of breast cancer patients. After that, we used MethSurv to determine the expression and prognostic patterns of single CpG methylation of the NEK gene family in breast cancer. Then, we studied the gene potential of the NEK family in depth through functional enrichment analysis and miRNA-regulated networks. This analysis was used to reveal the biological processes, molecular pathways, potentially regulated miRNAs, and their involvement in cell cycle kinases. In addition, we also used MetaCore to delve deeper into the enrichment pathways of potential NEK family genes in breast cancer development. Finally, we used the TIMER database to uncover the correlation of potential genes from the NEK family with immune cell markers in breast cancer.

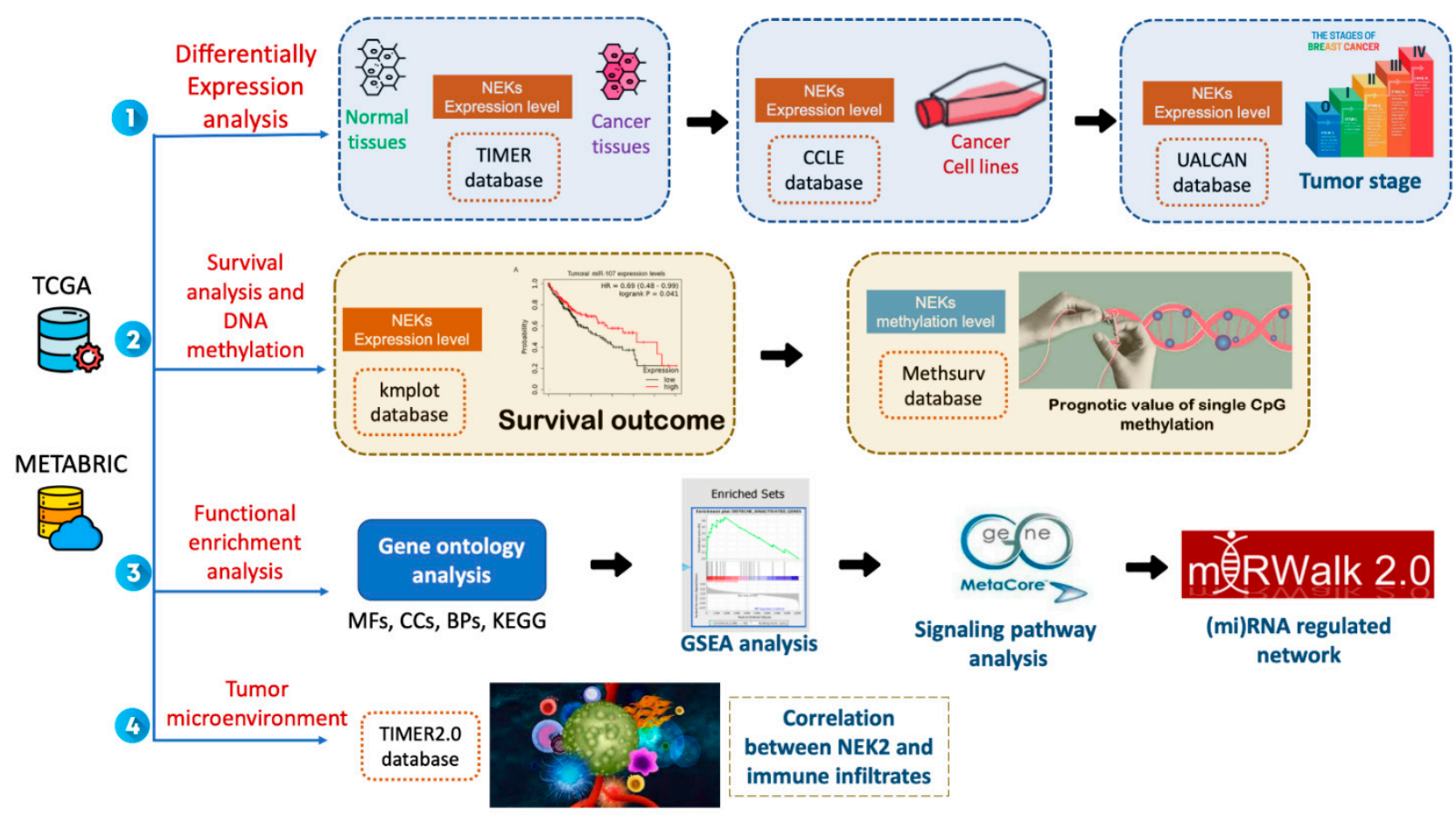

Figure 1. The workflow and study design of the analysis steps. TCGA: The Cancer Genome Atlas; METABRIC: Molecular Taxonomy of Breast Cancer International Consortium; NEK: NIMA-related kinase; GSEA: gene set enrichment analysis; BP: biological process; MF: Molecular Function; CC: Cellular Component; KEGG: Kyoto Encyclopedia of Genes and Genomes; CCLE: Cancer Cell Line Encyclopedia; MetaCore Analysis; micro (mi)RNA-regulated networks; TIMER: Tumor IMmune Estimation Resource.

\section{Materials and Methods}

\subsection{Expression Analysis of the NEK Genes Family}

We used the tumor immune estimation resource (TIMER), Cancer Cell Lines Encyclopedia (CCLE), and UALCAN to determine differences in NEK gene family expressions between breast cancer and normal tissues. Through the DiffExp module in the TIMER database (https:/ / cistrome.Shinyapps.io/timer/, accessed on 12 May 2020), we 
revealed differential expression patterns between normal and adjacent tumor tissues for each gene of interest in all TCGA tumors [44,45]. Furthermore, CCLE database (https:/ / portals.broadinstitute.org/ccle, accessed on 12 May 2020) contains 1457 cancer cell lines $(n=1457)$ with 136,488 unique data $(n=136,488)$; therefore we used the CCLE to explore the expression of NEK family members in these cancer cell lines. UALCAN (http:/ / ualcan.path.uab.edu, accessed on 12 May 2020) contains omics cancer data (TCGA, MET500, and CPTAC) [46], which we then used to investigate the expressions of NEK gene family members in normal and breast cancer tissues, and their clinicopathological significance. Furthermore, we used an independent-sample $t$-test to confirm the significance of expressions of NEK gene family members by normal and breast cancer tissues, and in terms of clinicopathological parameters. We used $p<0.05$ for the threshold of concluding that there was a significant difference [47-49].

\subsection{Survival Analysis of the NEK Genes Family}

The KM plotter (http://kmplot.com/analysis/, accessed on 12 May 2020) has a dataset of about 54,000 genes [50], and survival information on several cancer types with a known sample of 7830 breast cancers $(n=7830)$ [51]. These data were used to explore the significance of NEK gene family members on distant metastasis-free survival (DMFS) in breast cancer patients. The hazard ratio (HR) with $95 \%$ confidence interval (CI) and log-rank $p$ values were used to determine the significance of the overexpression of NEK family genes in terms of DMFS in breast cancer patients [52-54].

\subsection{DNA Methylation of the NEK Genes Family}

DNA methylation plays a vital role in prognostic assessment and potential biomarker in cancer development [55]. We used MethSurv (https://biit.cs.ut.ee/methsurv/, accessed on 12 May 2020) to determine the expression and prognostic patterns of single CpG methylation of the NEK gene family in breast cancer [56]. In this analysis, DNA methylation values are represented using beta values (beta values ranging from 0 to 1). Every single methylation of $C p G$ was calculated by the $M /(M+U+100)$ formulation. $M$ and $U$ are methylated and unmethylated intensity values.

\subsection{Functional Enrichment and Micro (mi)RNA-Regulated Networks Analysis}

We used the Bioconductor "clusterProfiler" and "GOplot 1.0.2" packages in R Studio software $[57,58]$ to test the potential functional significance of genes with molecular functions (MFs), cellular components (CCs), and biological processes (BPs) on GO and the Kyoto Encyclopedia of Genes and Genomes (KEGG) [59]. An adjusted $p<0.05$ was chosen as the threshold for statistical significance. Next, we used the "fgsea" packages in R Studio software to evaluate enriched pathways in transcriptional data by a GSEA $[60,61]$. This study used a hallmark database analysis to display gene enrichment pathways in transcriptional data [62-64]. Furthermore, MetaCore (https:/ / portal.genego. $\mathrm{com} /$, accessed on 12 May 2020) was used to perform functional analyses on various omics data, which calculates the $p$-value of enrichment in different gene pools of an uploaded dataset [65-69]. Expression profiles of TCGA dataset on expressions of NEK gene family members were collected and in-depth integrated, by applying Venny vers. 2.1 (https:/ / bioinfogp.cnb.csic.es/tools/venny/index.html, accessed on 12 May 2020), and results were subsequently uploaded to MetaCore for analysis. Finally, we also investigated the gene potential of the NEK family with miRNAs. We used miRWalk (http: //mirwalk.umm.uni-heidelberg.de/, accessed on 12 May 2020) to investigate the regulatory potential of miRNAs, analyzing regulated pathways and networks by Ingenuity Pathway Analysis (IPA) [70-74].

\subsection{Correlation Analysis between Gene Expressions and Immune Infiltration}

TIMER 2.0 (http:/ / timer.cistrome.org/, accessed on 12 May 2020) was used to examine the relationships among immune cells and various types of cancer [44,45]. This 
platform applies an algorithmic method to evaluate the abundances of immune cells that infiltrate tumor genes' expression profiles. We investigated associations of potential expressions of NEK gene family members with the quantity of immune infiltrates in breast cancer through this dataset. The main objective was to find potential biomarkers at the level of immune infiltration in breast cancer tissues. We studied potential associations of gene expressions of the NEK family with various levels of infiltration such as purity, B cells, cluster of differentiation-positive $\left(\mathrm{CD}^{+}\right) \mathrm{T}$ cells, $\mathrm{CD} 4^{+} \mathrm{T}$ cells, macrophages, neutrophils, and dendritic cells (DCs) [75,76]. The TIMER 2.0 analysis displays scatterplots and heatmaps to illustrate correlations between gene expressions and levels of immune infiltration. Next, we used Spearman correlation measures, $p$ values, and adjusted $p$ values to make statistical decisions.

\section{Results}

\subsection{Expression Analysis of NEK Family Members in Breast Cancer}

In this study, we used TIMER, CCLE, and UALCAN databases (Figures 2-4) to reveal the transcriptional expressions of 11 genes of the NEK family. We determined the distributions of gene expression levels using the TIMER database, which are displayed in a box plot. This study found significant differences between normal and breast cancer tissues, and we determined that differences in NEK1/2/3/5/6/7/8/9/10 expressions were statistically significant at $p<0.001$ (Figure 2A). In addition, we also studied expression levels of NEK gene family members in breast cancer cell lines using the CCLE database (Figure 2B).

Next, we studied mRNA expression patterns of the NEK family that differed between normal and breast cancer tissues using the UALCAN database, and also reflected clinical parameters such as tumor stage (Figures 3 and 4 ). Differences in expressions of NEK1/2/3/4/5/6/7/8/9/11 were statistically significant $(p<0.05)$ between normal and breast cancer tissues (Figure 3A-J). Furthermore, we found that NEK1/2/3/7/9/10 mRNA expressions had a trend with higher statistical significance in more advanced tumors based on tumor stage indicators (Figure 4A-K).

\subsection{Prognostic Value of the NEK Family Members in Breast Cancer}

We analyzed a breast cancer database with the KM plotter (Figure 5), to unveil the prognostic significance of values of overexpression of NEK family genes on DMFS in breast cancer patients. The KM curve investigation and log-rank test revealed higher expression levels of NEK1/2/4/6/8/9/10/11 mRNA, and these were significantly correlated with a poor DMFS. As to DMFS, we concluded that most NEK genes were significantly correlated with the prognosis of breast cancer patients: NEK1 ( $\mathrm{HR}=0.81,95 \% \mathrm{CI}=0.69 \sim 0.96, p=0.049)$, NEK2 (HR $\left.=1.89,95 \% \mathrm{CI}=1.61 \sim 2.23, p=7 \times 10^{-15}\right)$, NEK4 $(\mathrm{HR}=0.82,95 \% \mathrm{CI}=0.69 \sim 0.97$, $p=0.023)$, NEK6 $(\mathrm{HR}=1.49,95 \% \mathrm{CI}=1.13 \sim 1.98, p=0.0048)$, NEK8 $(\mathrm{HR}=1.49,95 \%$ $\mathrm{CI}=1.1 \sim 2, p=0.0087), N E K 9(\mathrm{HR}=0.64,95 \% \mathrm{CI}=0.55 \sim 0.75, p=0.049), N E K 10(\mathrm{H}=0.45$, $\left.95 \% \mathrm{CI}=0.32 \sim 0.62, p=7 \times 10^{-7}\right)$, and NEK11 $(\mathrm{HR}=0.74,95 \% \mathrm{CI}=0.56 \sim 0.99, p=0.042)$.

\subsection{DNA Methylation Analysis of the NEK Family Members in Breast Cancer}

DNA methylation is an epigenetic alteration that plays a role in the development of several cancers [77]. DNA methyltransferases on CpG island methylation are transcription factors in the suppression or promotion of cell growth and it is a reversible process [78]. We present heatmap and prognostic value of DNA methylation clustering the expression levels of the NEK gene family in breast cancer (Figure S1 and Table S1 in Supplementary). DNA methylation expression levels concluded that cg17931972 from NEK2 and cg14289738 from NEK6 had the highest DNA methylation levels and significant prognostic value (likelihood ratio (LR) test $p$-value $<0.05)$ in breast cancer. 
(A)
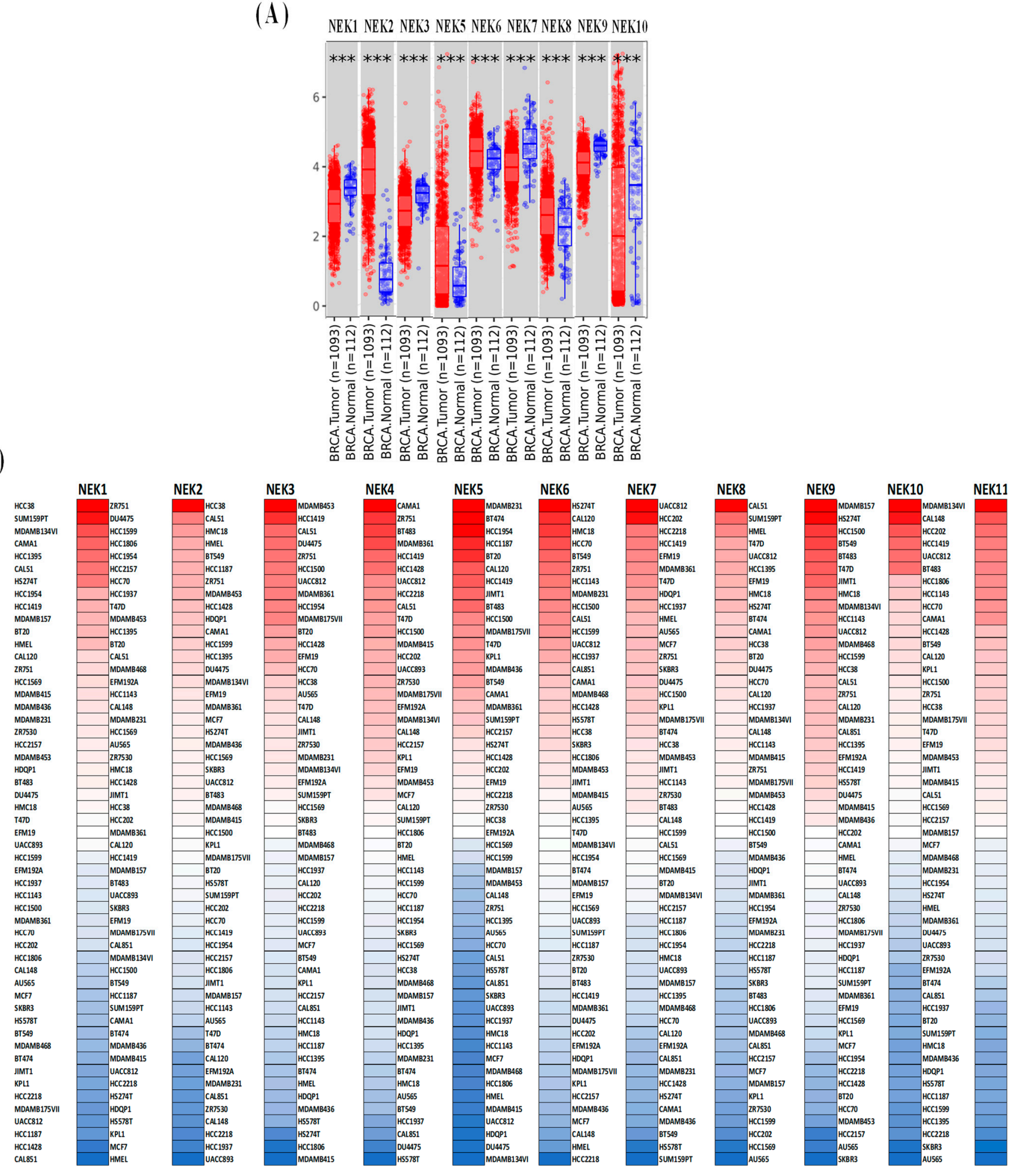

(B)

Figure 2. Expression of the NEK gene family in breast cancer. (A) Box plot of the NEK gene family's transcripts in normal and breast cancer tissues in the TIMER database. Statistical significance was calculated using the Wilcoxon test, ${ }^{* * *} p<0.001$. (B) Heatmap of the NEK gene family's expression levels in breast cancer cell lines (CCLE). We used mRNA expression values from the CCLE database, and then displayed them by their ranking. In CCLE, red represents overexpression (top column) and blue indicates under-expression (bottom column). 
(A) Expression of NEK1

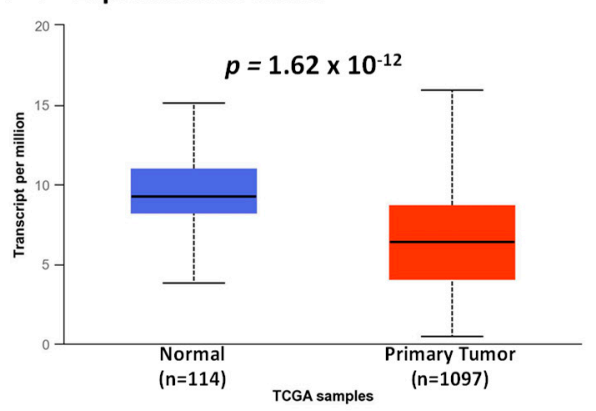

(D) Expression of NEK4

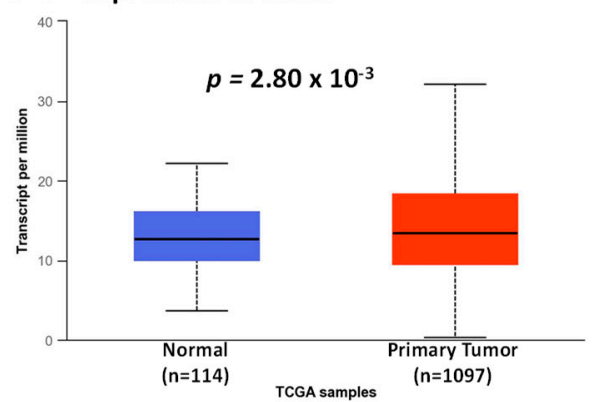

(G) Expression of NEK7

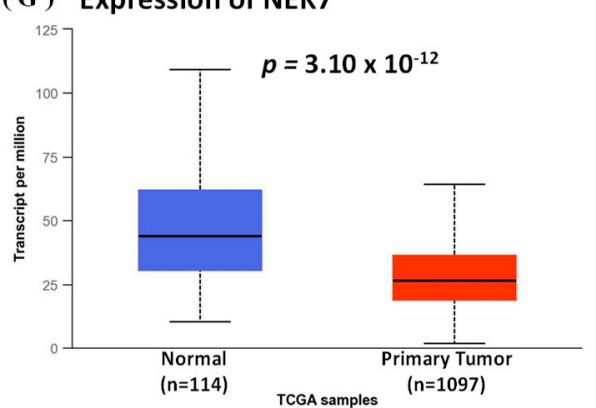

(J) Expression of NEK11

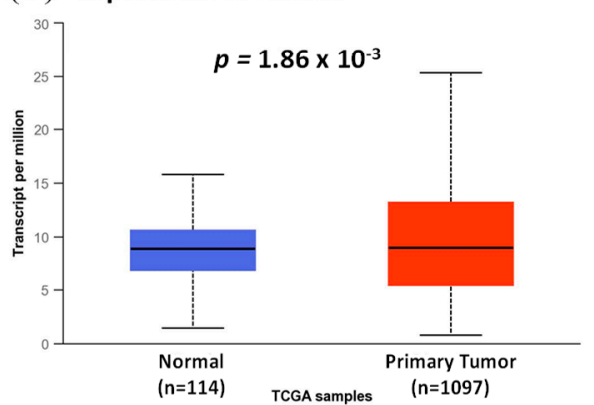

(B) Expression of NEK2

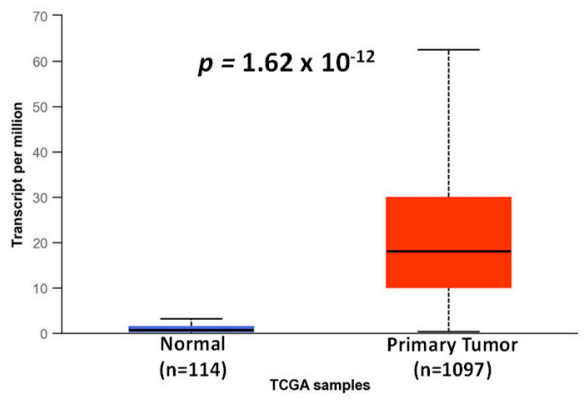

(E) Expression of NEK5

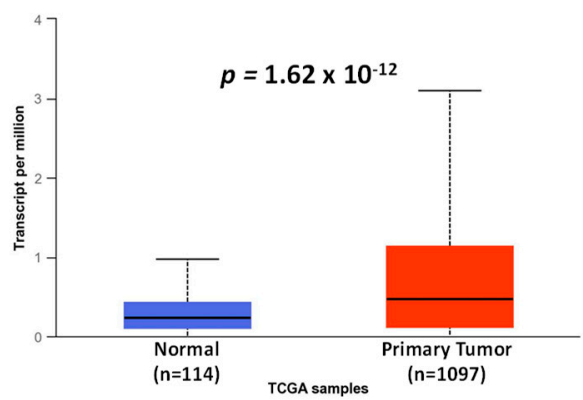

(H) Expression of NEK8

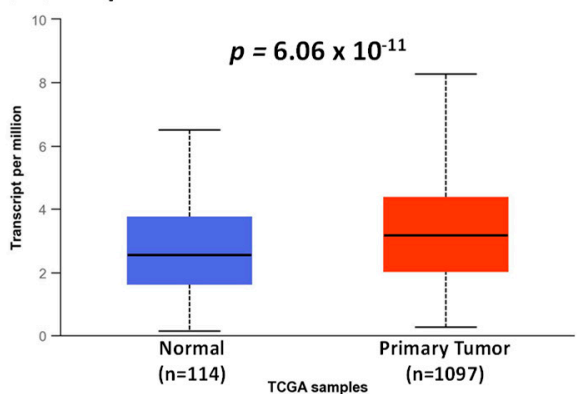

(C) Expression of NEK3

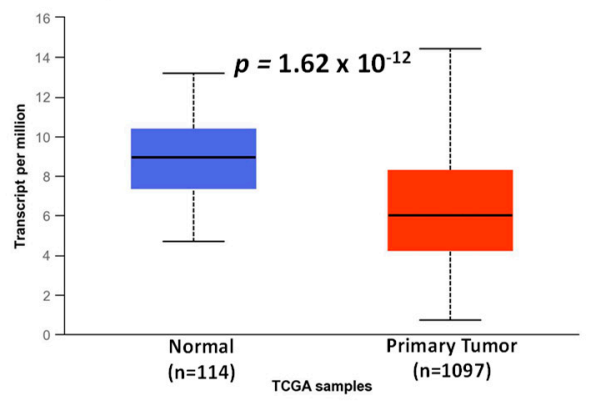

(F) Expression of NEK6

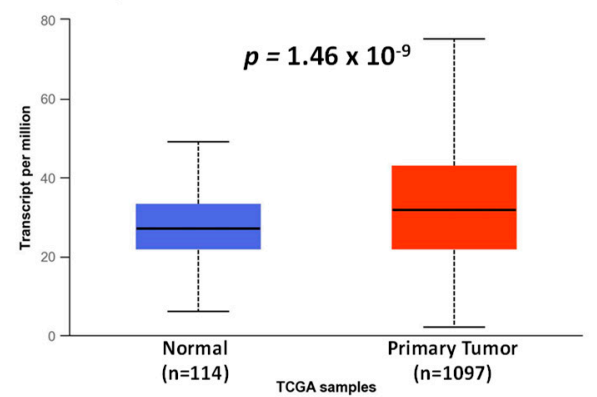

(I) Expression of NEK9

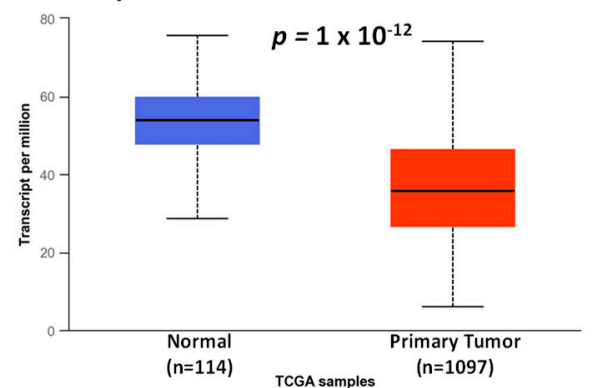

Figure 3. Expression of the NEK gene family in breast cancer (UALCAN Analysis). (A-J) Box plot of NEK gene family transcripts in normal and primary tumor (BRCA) tissues. The box plot shows comparisons of the expressions of TCGA data from the NEK gene family in breast cancer, between normal samples $(n=114)$ and primary tumors $(n=1097)$. Statistical significance is represented by $p<0.05$. 
(A) Expression of NEK1

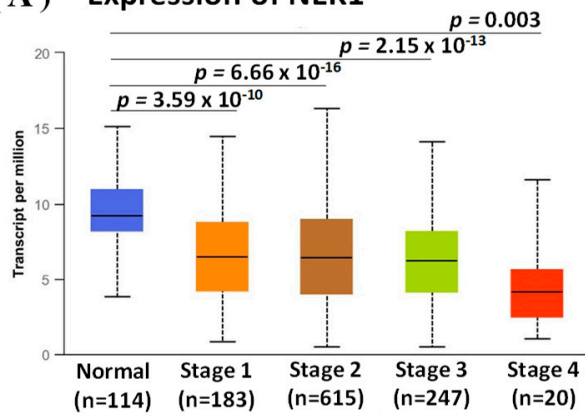

(D) Expression of NEK4

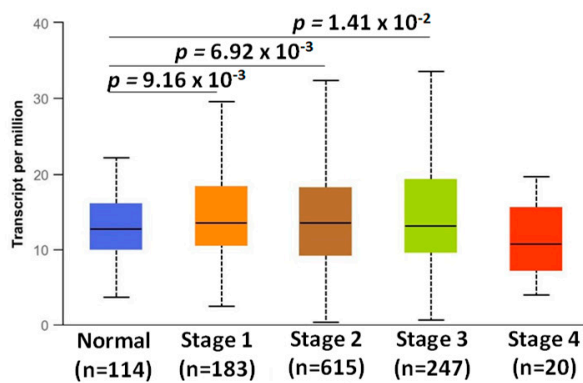

( $\mathrm{G}$ ) Expression of NEK7

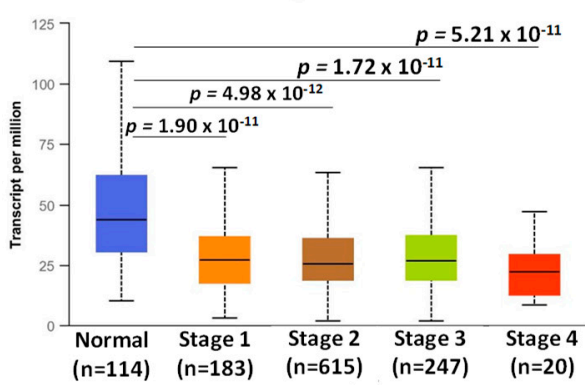

( J ) Expression of NEK10

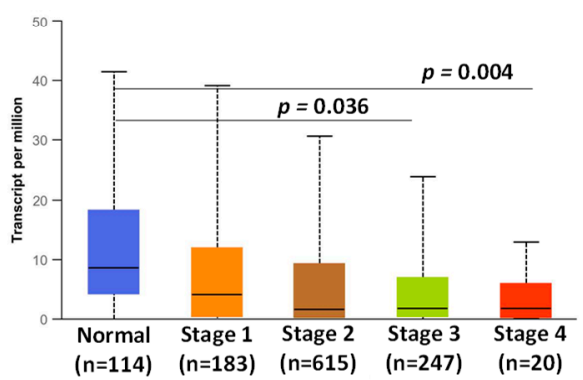

(B) Expression of NEK2

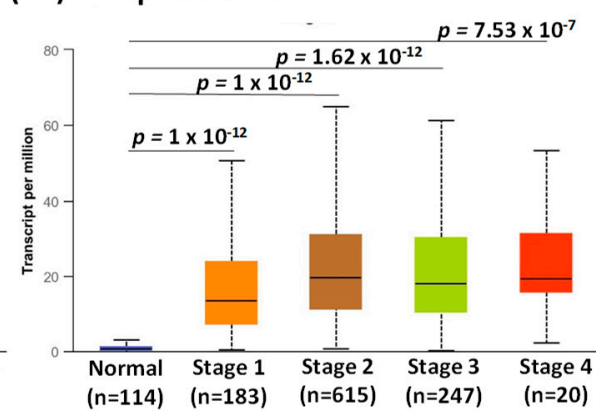

( E) Expression of NEK5

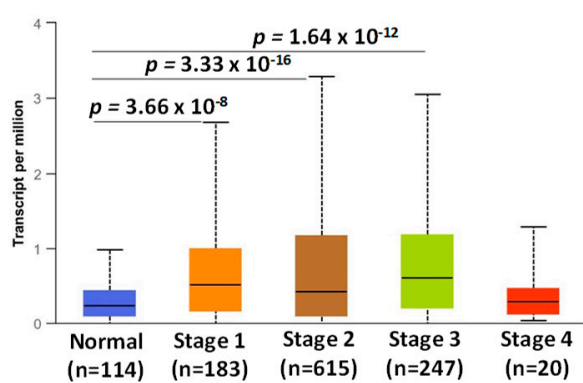

(H) Expression of NEK8

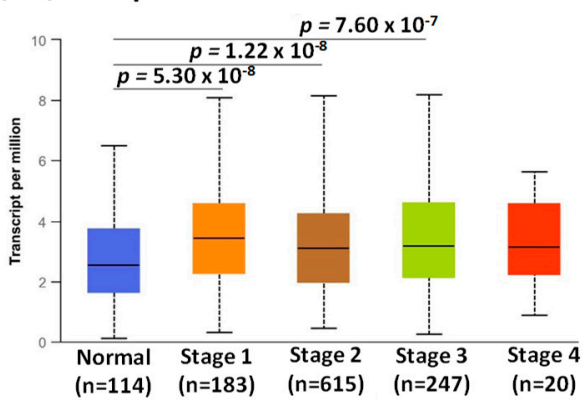

\section{( I) Expression of NEK9}

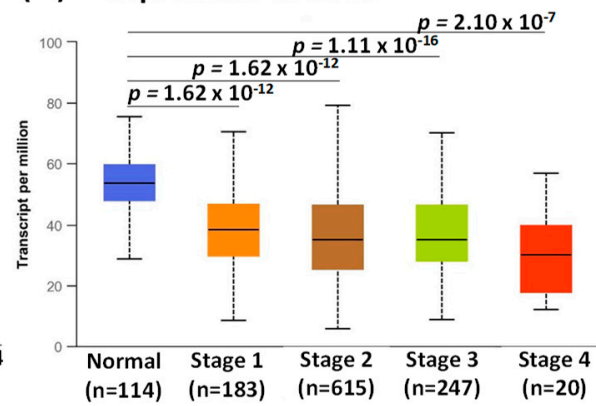

(C) Expression of NEK3

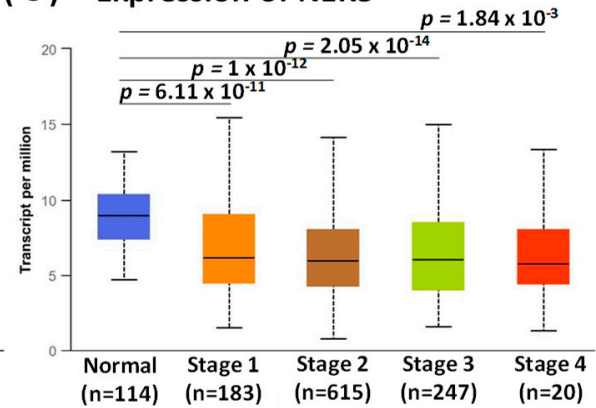

( F ) Expression of NEK6

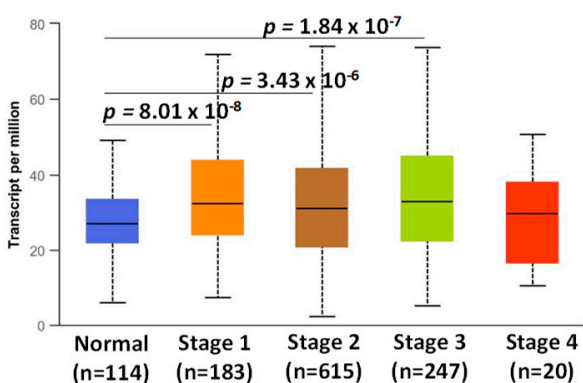

(K) Expression of NEK11

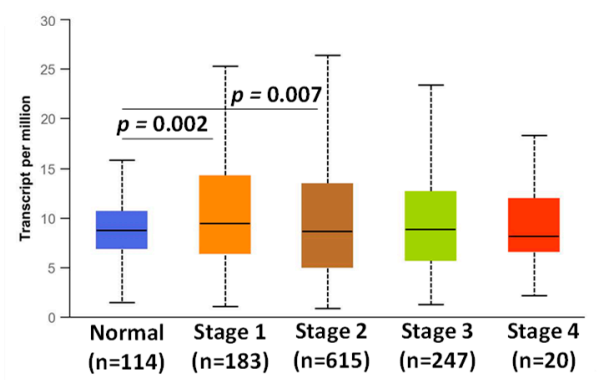

Figure 4. Expression transcript levels of the NEK gene family in normal tissues with individual cancer stages or clinicopathology (UALCAN analysis). (A-K) Box plots of the NEK gene family transcripts in normal tissues and various tumor stages (breast cancer, BRCA). An independent $t$-test was used to calculate $p$ values. Statistical significance was indicated by $p<0.05$.

Collectively, the results of several integrative analyses such as TIMER, CCLE, UALCAN, survival analysis with the KM plotter, and DNA methylation revealed that several NEK family genes were consistently overexpressed in breast cancer. In the TIMER database, we found that NEK1/2/3/5/6/7/8/9/10 had significant $p$ values $<0.001$, and in the CCLE analysis, we also found overexpression levels of NEK gene family members in breast cancer cell lines. In the UALCAN analysis, we discovered that NEK1/2/3/4/5/6/7/8/9/11 were statistically significantly overexpressed in breast cancer compared to normal tissues. Furthermore, we found that NEK1/2/3/7/9/10 were overexpressed in terms of clinico- 
pathological indicators and had higher statistical significance in more advanced tumors. We found a significant result in the survival analysis, which revealed that NEK2/6/8 had high HRs and overexpression prognostic significance in DMFS in breast cancer patients. DNA methylation analysis also concluded that NEK2/6 had the highest level of DNA methylation and a significant prognostic value (likelihood ratio (LR) test $p$-value $<0.05$ ) in breast cancer. Therefore, this study further explored the NEK2 gene by investigating MFs, CCs, and BPs using GO and KEGG. Enriched pathways in transcriptional data were evaluated by a GSEA. A functional analysis was conducted on various omics data, which calculated $p$ values of enrichment across different gene pools in datasets uploaded on the MetaCore platform. Then, this study also investigated the relationship of NEK2 with miRNA-regulated networks. Finally, we also studied the correlation of NEK2 transcriptional levels with immune infiltration.
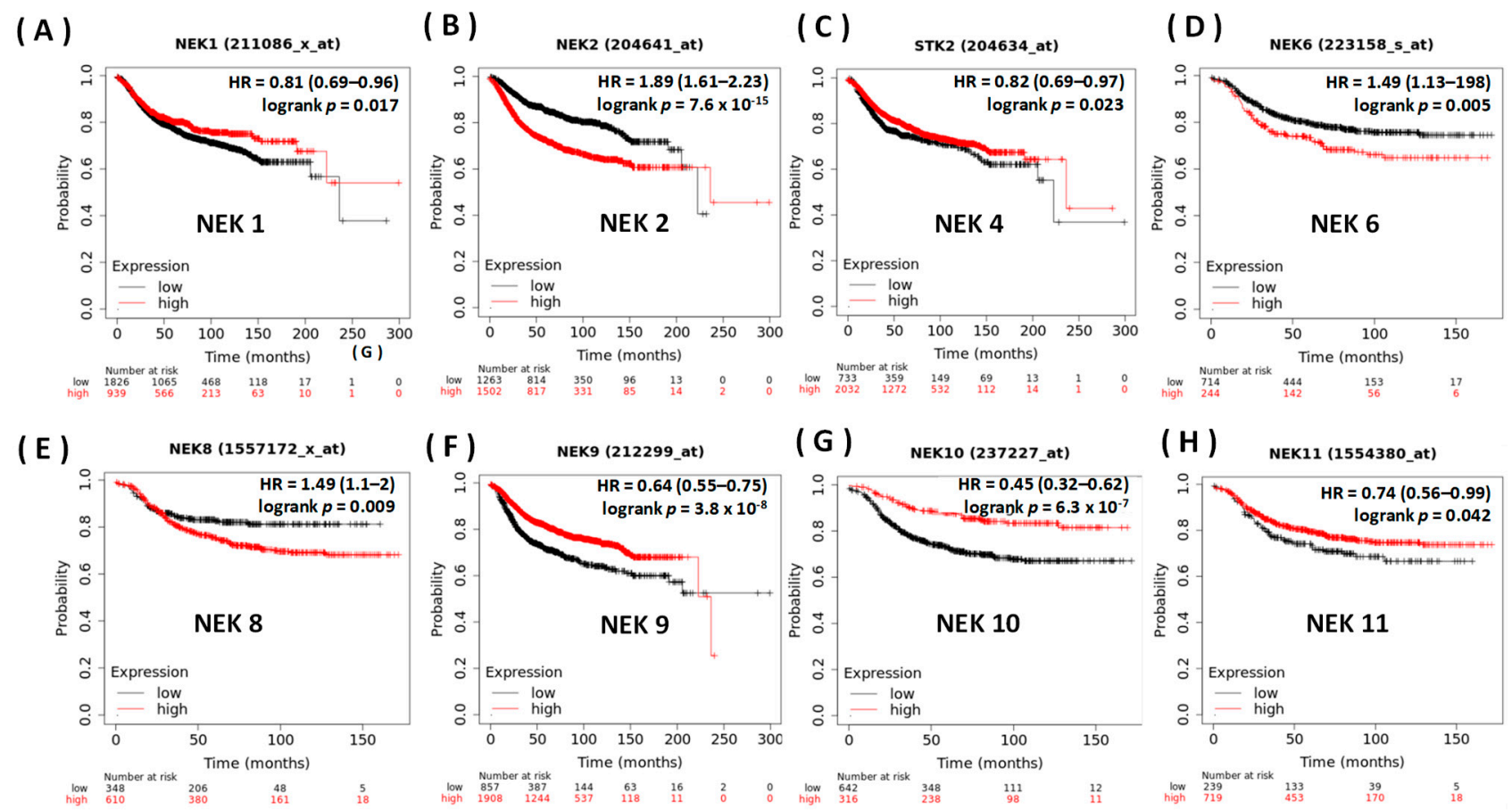

Figure 5. Survival curve of the NEK gene family on distant metastasis-free survival (DMFS) in breast cancer patients (Kaplan-Meier plotter). The hazard ratio (HR) is a relative prognostic measure of patients with breast cancer. $\operatorname{logrank} p$ was used to determine the level of prognostic significance of patients with breast cancer. Furthermore, the $\log \operatorname{rank} p<0.05$ was interpreted as a significant difference in the prognostic expression of patients with breast cancer.

\subsection{Regulated Networks of NEK2 Gene Expressions in Breast Cancer}

This study performed a GO analysis based on genes co-expressed by NEK2 from associated METABRIC and TCGA datasets (Figure 6). This analysis investigated BPs, CCs, and MFs that were affected under the conditions studied. We found that genes co-expressed with NEK2 from the METABRIC and TCGA datasets were involved in organelle fission, nuclear division, and chromosome segregation in BPs (Figure 6A); ATPase activity, tubulin binding, and catalytic activity-acting on DNA in MFs (Figure 6B); chromosomal region, chromosome-centromeric region, and the spindle in CCs (Figure 6C); and cell cycle, oocyte meiosis, and cellular senescence in KEGG (Figure 6D). We also studied the differential involvement of gene expressions (DEGs) with GO terms of BPs and KEGG displayed in chord plots, and we found it to be mostly upregulated (Figure 6E,F). 

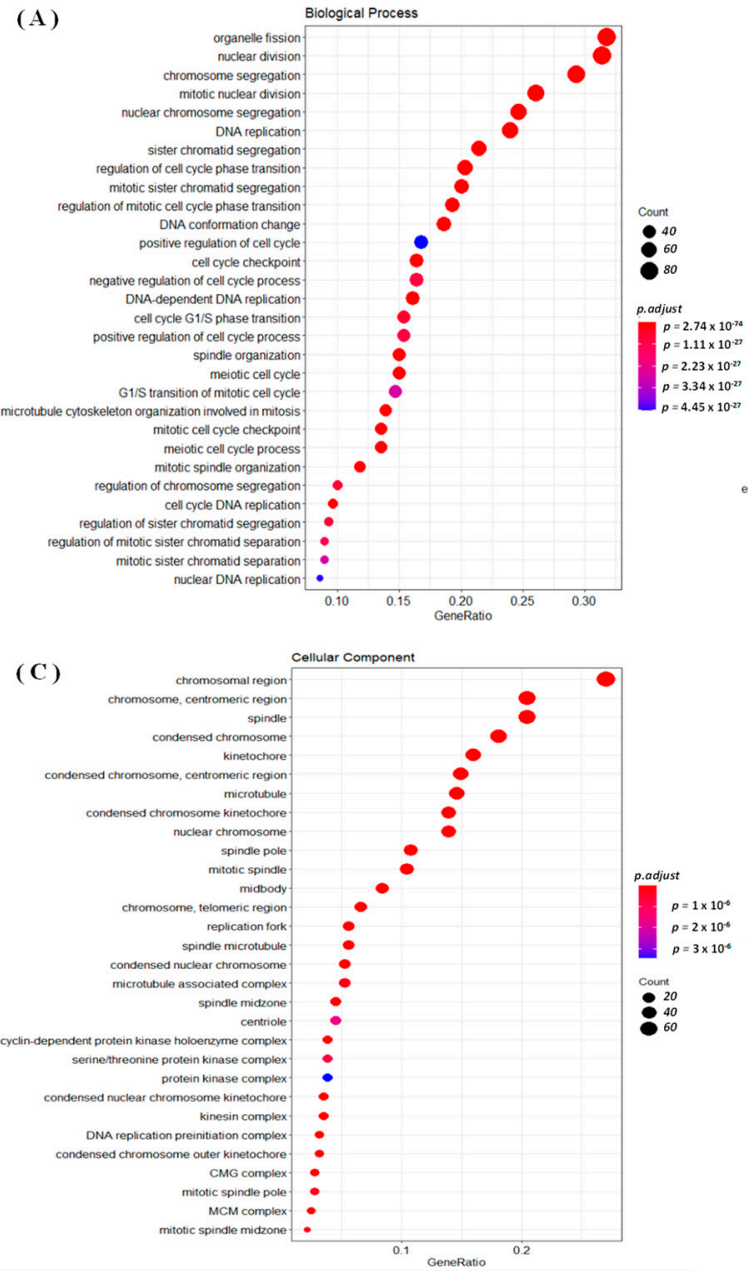

( E)

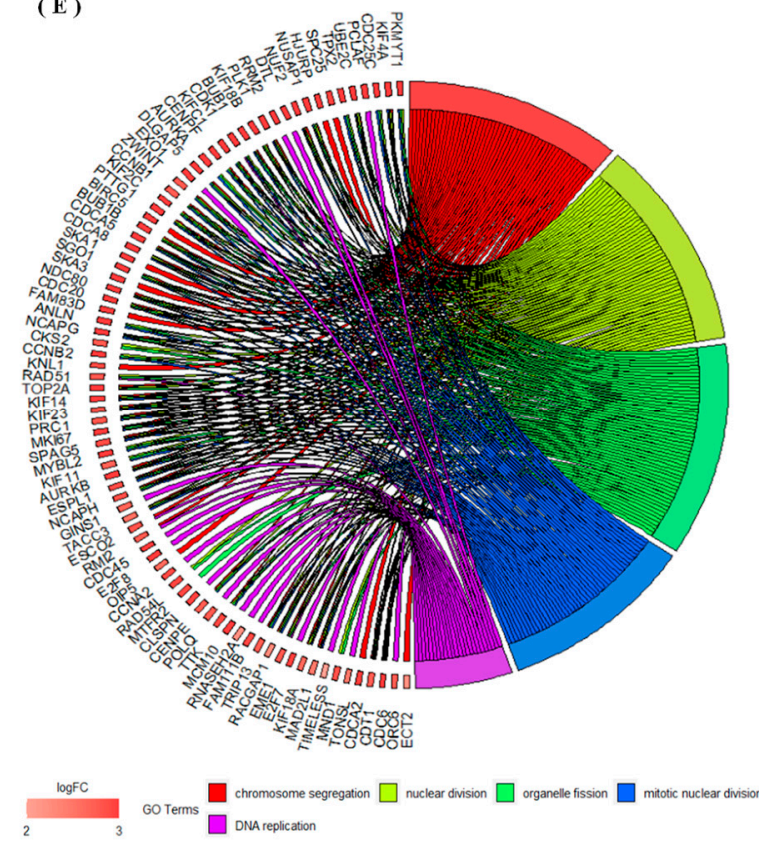

(B)

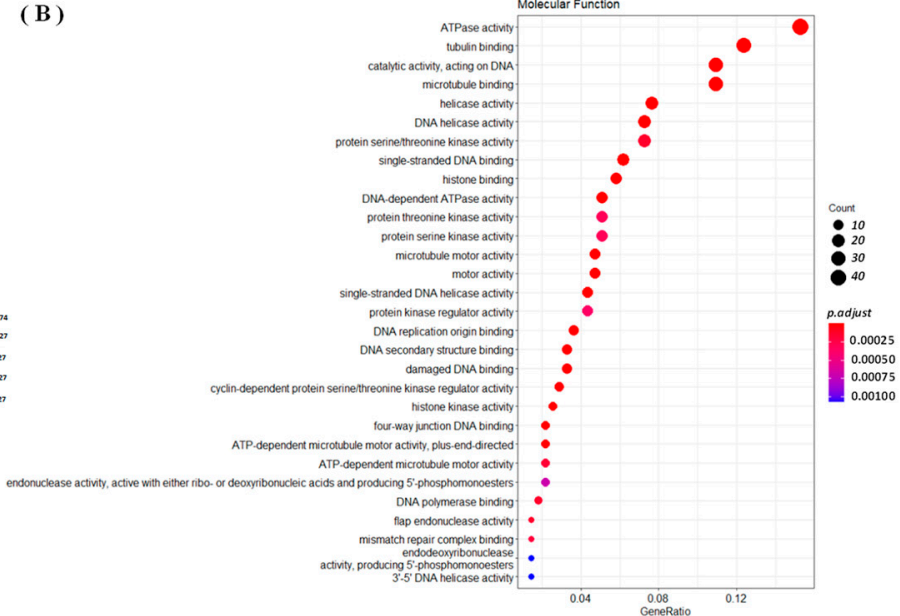

(D)

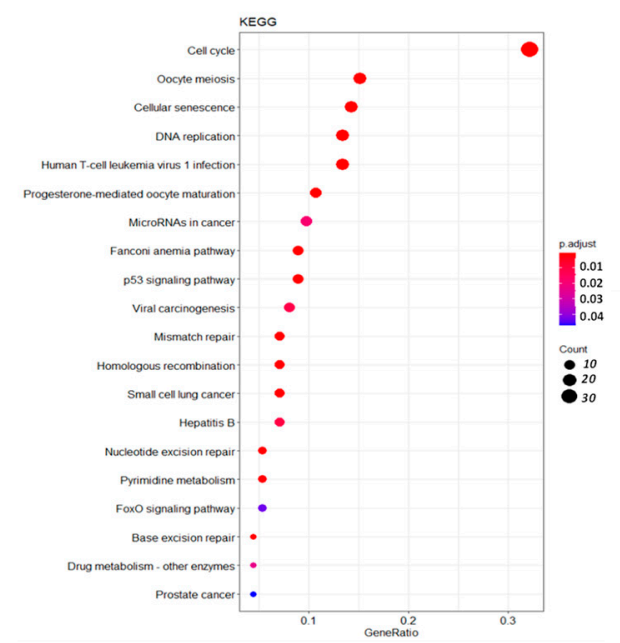

(F)

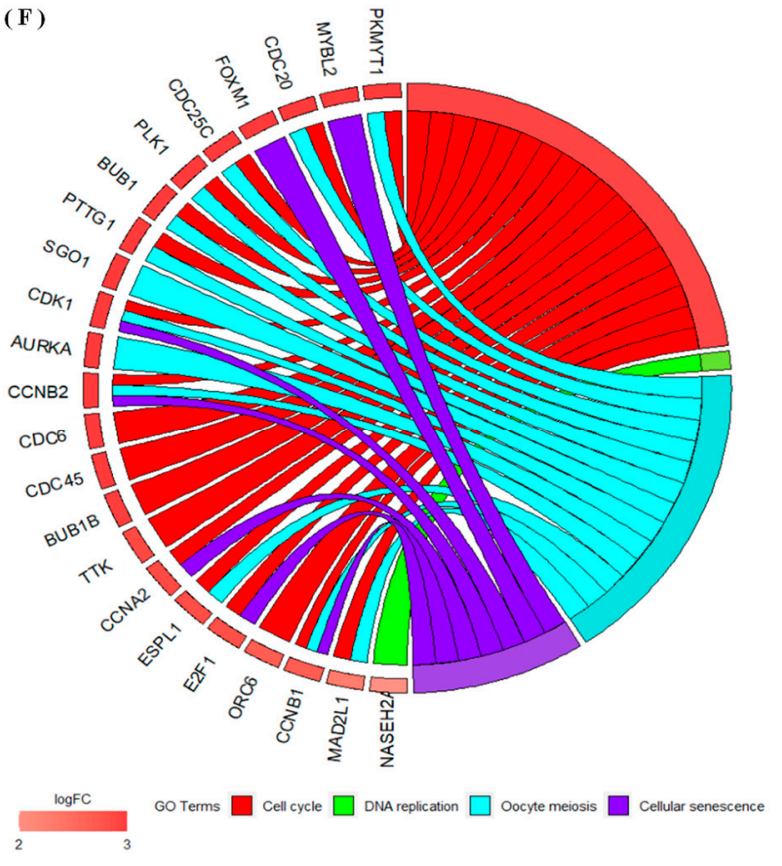

Figure 6. Gene ontology (GO) analysis based on genes co-expressed with NEK2 from the associated METABRIC and TCGA 
datasets. (A) Dot plot of biological processes. (B) Dot plot of cellular components. (C) Dot plot of molecular functions. (D) Dotplot of KEGG. The dot size is determined by the count of enriched genes in the pathway, and the color of the dots represents the pathway enrichment's significance. We used the "clusterProfiler" package in R/Bioconductor to perform the GO analyses of dot plots. (E) Chord plot of relationships between genes and GO terms of biological processes. (F) Chord plot of relationships between genes and GO terms of KEGG.

GSEA results revealed that hallmark analysis signaling pathways significantly involved E2F targets, G2M checkpoint, MYC targets, MTORC1 signaling, and DNA repair (Figure 7A-C, Table S2 in Supplementary). We used the MetaCore platform to reveal the functions, enrichment pathways, and network analyses of the NEK2 gene in breast cancer. NEK2 co-expressed genes from the METABRIC and TCGA breast cancer datasets were analyzed by MetaCore and revealed that NEK2 co-expressed genes were involved in cell cycle process including "The metaphase checkpoint", "Role of APC in cell cycle regulation", "Chromosome condensation in prometaphase", "Start of DNA replication in early S phase", and "Spindle assembly and chromosome separation" in breast cancer development (Figure 8, Table S3 in Supplementary). Furthermore, analysis of miRNA-regulated networks with NEK2 also suggested that hsa-miR-1236-3p, hsa-miR-4264, hsa-miR-486$5 p$, hsa-miR-155-3p, and hsa-miR-6839-3p are also regulated breast cancer development (Figure S2 in Supplementary).

\subsection{Levels of Immune Infiltration in Breast Cancer Were Linked to Expression of NEK2}

The TIMER database was used to explore the immunological microenvironment and identified correlations between levels of immune infiltration and expressions of the NEK2 gene in breast cancer (Figure 9). NEK2 expression was significantly positively linked with immune infiltration of B cells $\left(\mathrm{r}=0.144, p=6.46 \times 10^{-6}\right)$, purity $(\mathrm{r}=0.215$, $\left.p=7.82 \times 10^{-12}\right), \mathrm{CD}^{+} \mathrm{T}$ cells $(\mathrm{r}=0.069, p=0.033)$, neutrophils $(\mathrm{r}=0.128, p=7.78$ $\left.\times 10^{-5}\right)$, and DCs $\left(r=0.137, p=2.11 \times 10^{-5}\right)$ (Figure 9A). Subsequently, we explored more deeply using several immune level algorithms of $\mathrm{B}$ cells and $\mathrm{CD} 4^{+} \mathrm{T}$ cells. Previous studies suggested that $\mathrm{B}$ cells and $\mathrm{CD} 4^{+} \mathrm{T}$ cells have essential functions in developing immune-based therapies in all disease subtypes [79-81]. This study found that NEK2 gene expression was positively and significantly correlated with B cell, such as the naïve XCELL $(\mathrm{r}=0.109, p=0.001)$, QUANTISEQ $(\mathrm{r}=0.180, p=0.000)$, XCELL $(\mathrm{r}=0.202, p=0.000)$, and Class-switched memory XCELL $(r=0.101, p=0.001)$ (Figure S3 and Table S4 in Supplementary). Furthermore, in terms of $\mathrm{CD}^{+} \mathrm{T}$ immune cells, we found that NEK2 gene expression was positively and significantly correlated with $\mathrm{T}$ cell CD4 ${ }^{+}$memory, such as the activated CIBERSORT $(\mathrm{r}=0.2223, p=0.000)$, activated CIBERSORT-ABS $(\mathrm{r}=0.2224$, $p=0.0000)$, resting CIBERSORT-ABS $(\mathrm{r}=0.1065, p=0.0008)$, XCELL $(\mathrm{r}=0.2963, p=0.000)$, Th1 XCELL $(r=0.1474 p=0.000)$, and Th2 XCELL $(r=0.6766, p=0.000)$ (Figure S4 and Table S5 in Supplementary). We also found associations between BPs of NEK2 in the GSEA analysis and immune categories. Expression of NEK2 correlated with hallmark interferon alpha and gamma responses $\left(p=1.54 \times 10^{-4}, \mathrm{NES}=1.78\right)$ and $\left(p=8.48 \times 10^{-3}, \mathrm{NES}=1.4\right)$, respectively (Figure 7B and Table S2 in Supplementary). 
(A)
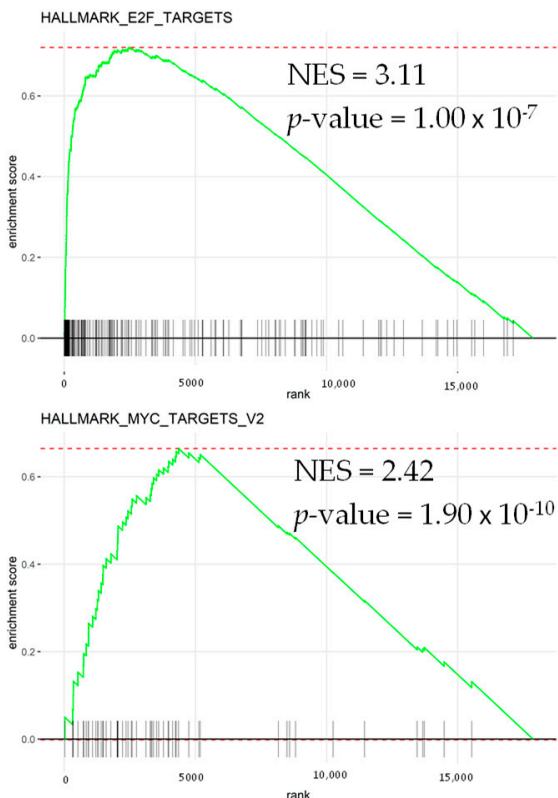

(B)

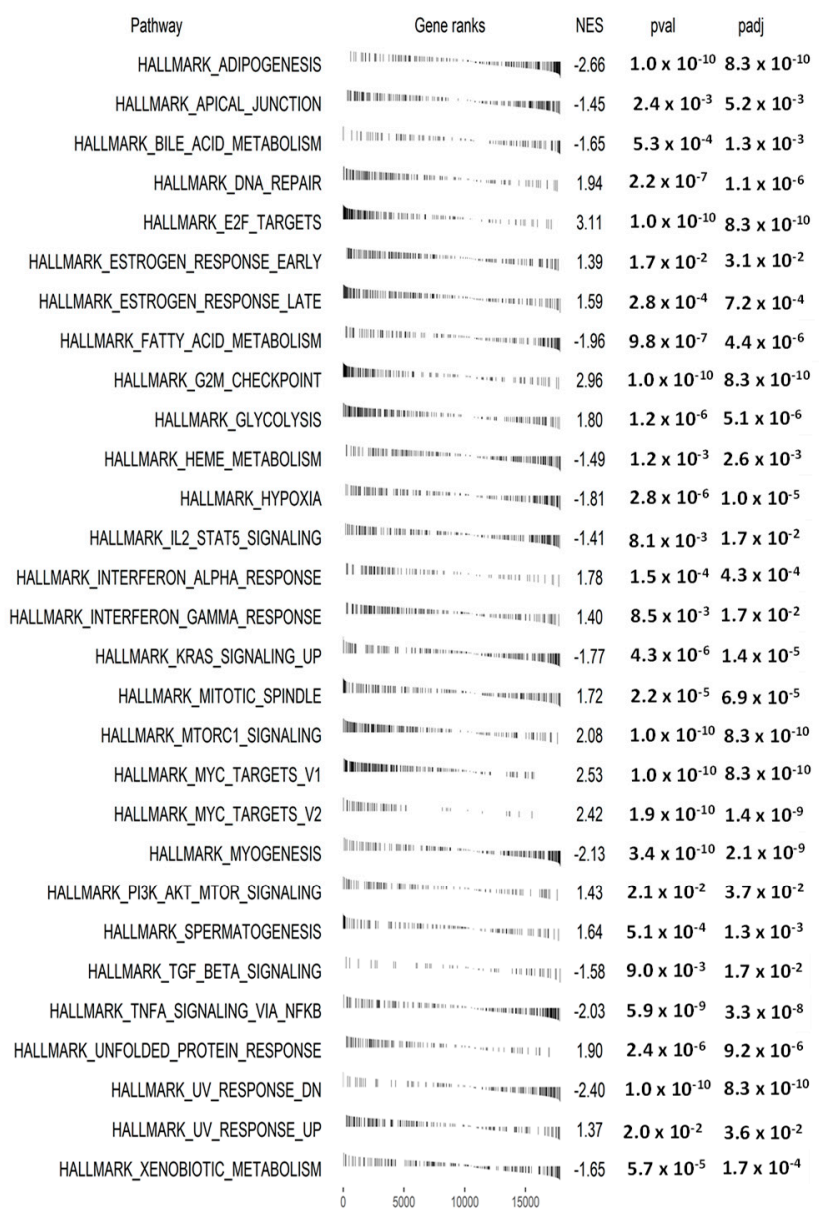

HALMARK GTM CHECKPOIT

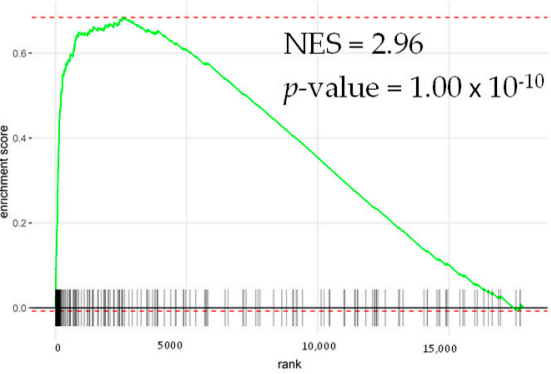

HALLMARK_MTORC1_SIGNALING

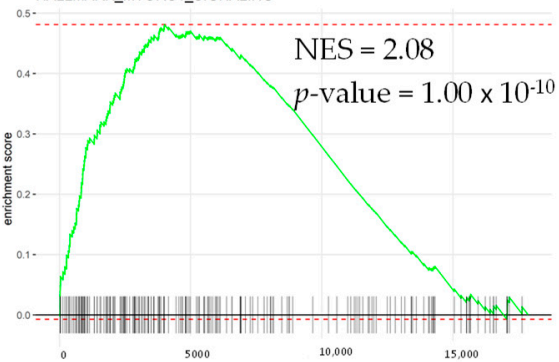

rank ${ }^{10,000}$

(C)

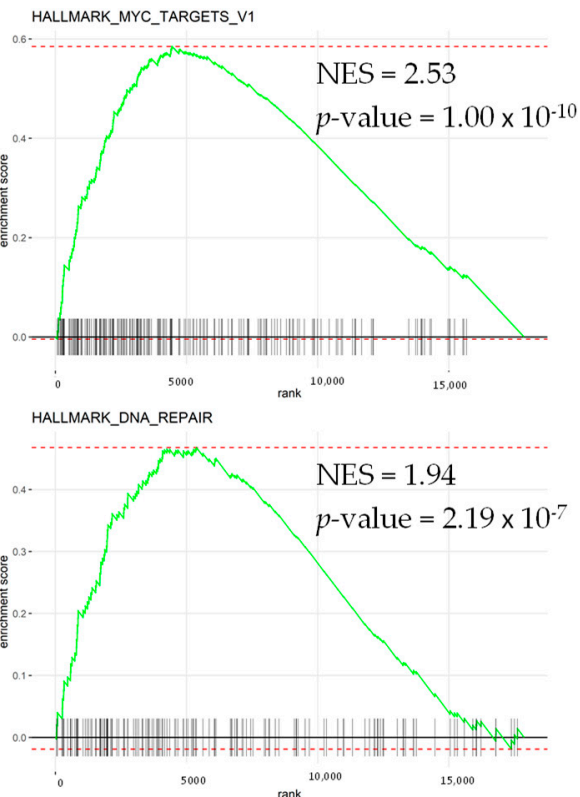

Hallmark pathways Enrichment Score NEK2 from GSEA

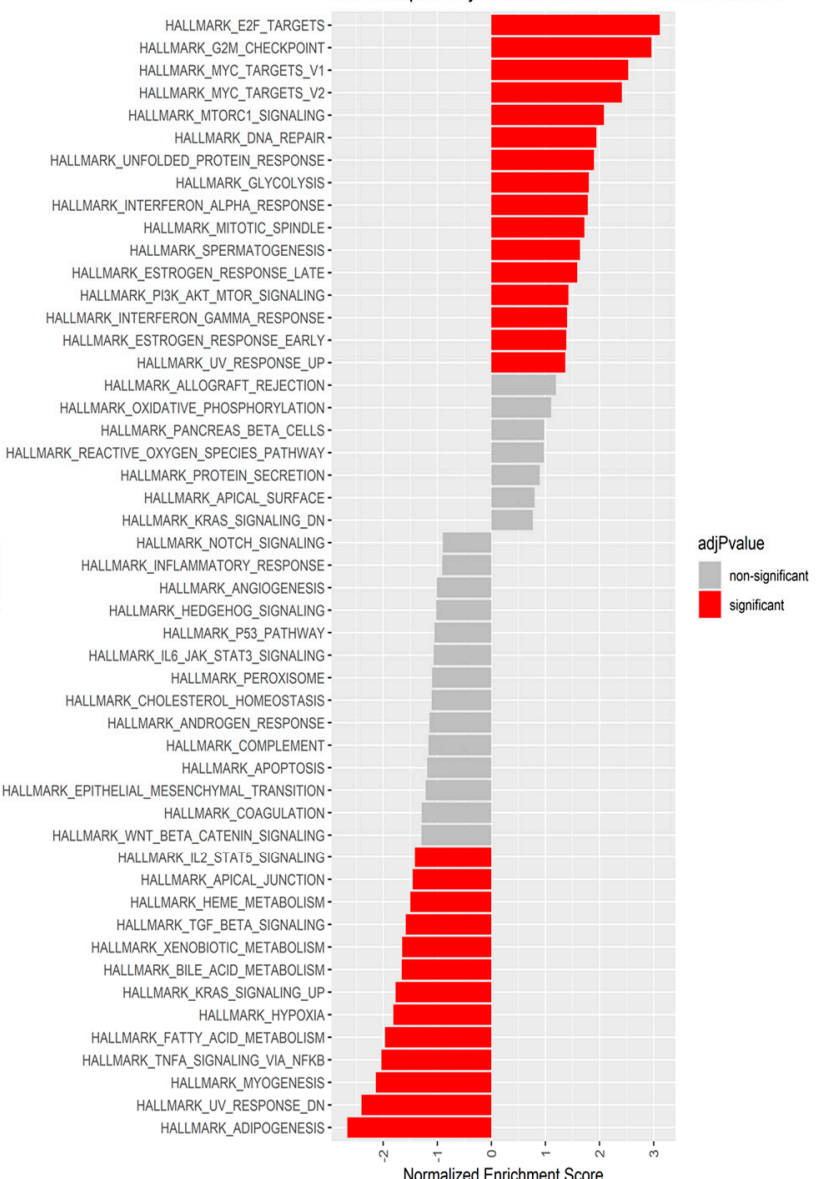
HALLMARK_E2F_TARGETSHALLMARK DNA REPAIR Normalized Enrichment Score

Figure 7. (A-C) Hallmark signaling pathway analysis of NEK2 in breast cancer. We used median expression of the NEK2 gene (high and low expression) and then performed a differential analysis using the algorithm in the "DESeq2" package in $\mathrm{R} /$ Bioconductor. Furthermore, results of the differential analysis were used as input for the gene set enrichment analysis (GSEA) with the Hallmark database, and computationally used the "fgsea" package in R/Bioconductor. Results of the analysis show significant values of gene classes in the Hallmark database. The level of statistical significance is shown through the $p$-value, and the normalized enrichment score (NES) reflects the rank of gene classes in the database. 


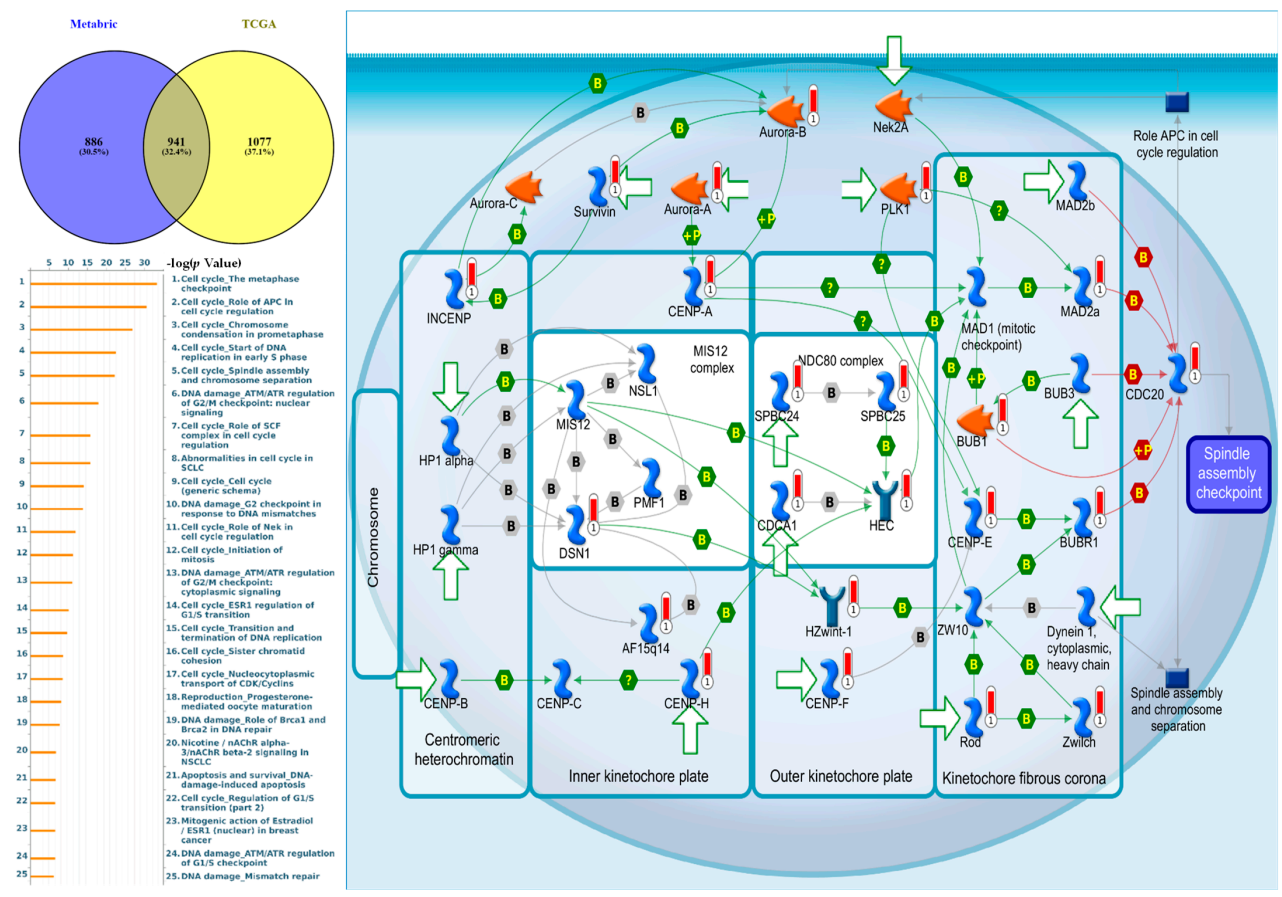

Figure 8. Expression of the NEK2 signaling pathway in breast cancer (MetaCore). We used the MetaCore platform to analyze genes co-expressed with NEK2 from the associated METABRIC and TCGA datasets, and we found that "Cell cycle_The metaphase checkpoint" was correlated with breast cancer development (with $p<0.05$ set as the cutoff value).

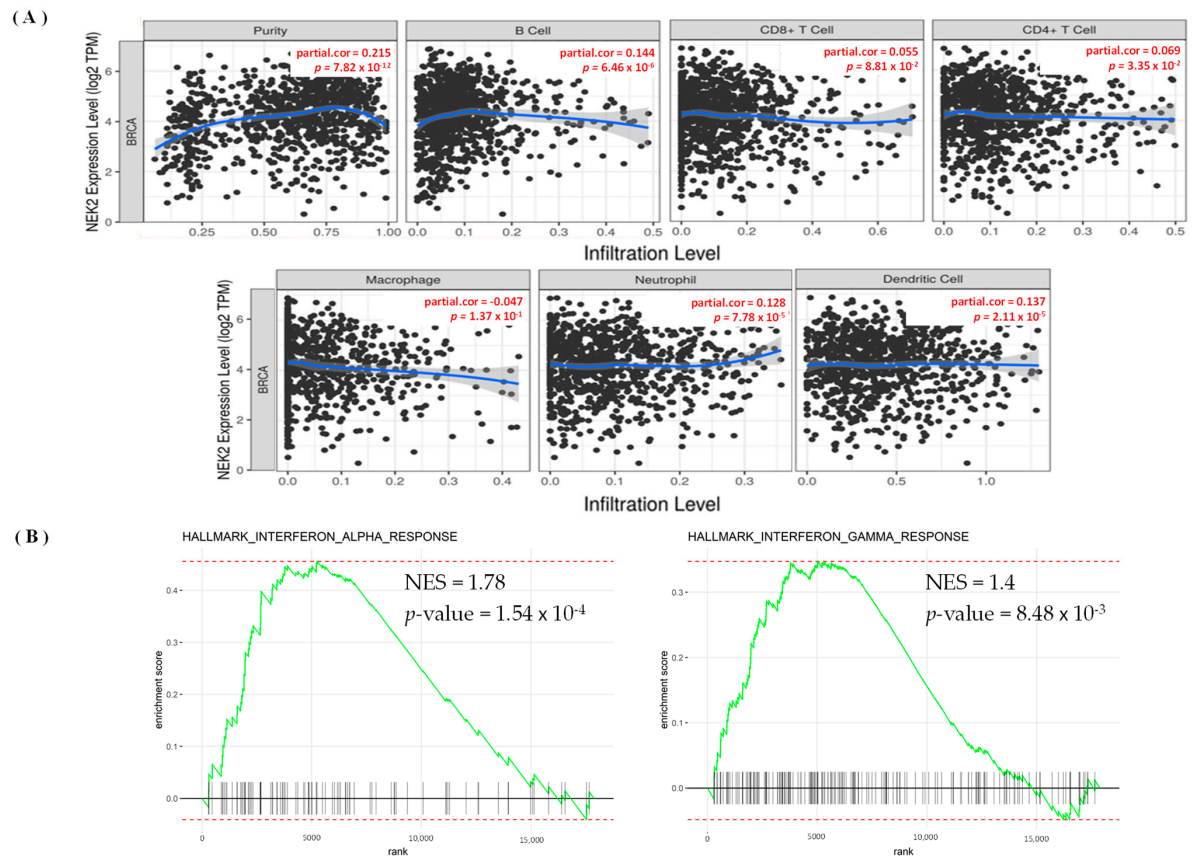

Figure 9. (A) Scatterplot of correlations among expressions of the NEK2 gene and levels of immune infiltration in breast cancer. Correlation of NEK2 with levels of immune infiltration (purity, B cells, CD8 ${ }^{+} \mathrm{T}$ cells, CD4 ${ }^{+} \mathrm{T}$ cells, macrophages, neutrophils, and dendritic cells). The correlation measurement is indicated by the partial correlation value using Spearman's partial rho and the statistical significance of the $p$ value. (B) GSEA analysis suggested that NEK2 expression could regulate the interferon alpha and gamma signaling in breast cancer. 


\section{Discussion}

According to previous studies, NEK dysregulation was linked to the occurrence and progression of several cancers $[82,83]$. We know that NEKs regulation processes of cell death and senescence in addition to tumor cell proliferation and differentiation $[82,84,85]$. Although the involvement of NEKs in the incidence and survival of some malignancies was reported, the holistic approach to explore the roles of distinct NEKs in the development of breast cancer still remains largely unexplored. Therefore, this is the first study to use bioinformatics and integrate data mining of biological databases to investigate transcription levels, and biological functions of distinct NEK family members in breast cancer, as well as their associations with prognosis and immunological infiltration in breast cancer patients. In further analysis, this study also investigated the effects of gene expressions on immune cell infiltration. Molecular and cellular factors of immune cell infiltration play essential roles in cancer BPs and are particularly useful in predicting OS and guiding treatment for patients with breast cancer [86-90]. We also investigated the interaction of a potential network of genes from the NEK family with miRNA. miRNA is a major posttranscriptional gene expression regulator known to play an important role in regulating cancer development [72,91,92].

Our comprehensive study of 11 members of the current, exploratory NEK gene family reveals that $N E K 2 / 6 / 8$ were closely related to the development of breast cancer in humans. We found a significant result in the survival analysis, which revealed that NEK2/6/8 have high HRs and overexpression prognostic significance in DMFS in breast cancer patients. Meanwhile, a previous study revealed that NEK2 has distinctly essential roles as a tumorsuppressor gene in different cancers, such as lung adenocarcinoma [75], ovarian cancer [76], hepatocellular carcinoma [93], and breast cancer [94]. The high expression of NEK2 has also been identified in prostate cancer [95]. Moreover, NEK6 also plays a role as a tumorsuppressor gene in different cancers, including thyroid cancer [96], gastric cancer [97], hepatic cell cancer [98], and breast cancer [99]. Furthermore, NEK8 is known to play a role in gastric cancer cells [100] and breast cancer [25], while NEK11 is known to play a role in ovarian cancer [101]. To reveal the prognostic potential of NEK2 and its relationship with other prognostics, we used integrated data analysis with high-throughput technology and several bioinformatics tools.

This study found that the NEK2 gene was significantly overexpressed in human breast cancer tissues compared to normal tissues through the TIMER and UALCAN exploration. Based on the clinicopathological characteristics of the tumor stage, we discovered that NEK2 mRNA expression tended to be significantly higher in more advanced tumor stages, whereas NEK6/8/11 mRNA expressions were only found in tumor stages 1,2, and 3 . In DNA methylation analysis, this study found that the prognostic value of NEK2/6 in a single $\mathrm{CpG}$ was significant in breast cancer development. We found prognostic significance of DNA methylation expression levels in cg17931972 from NEK2 and cg14289738 from NEK6. As a result of our investigation, we found that NEK2 consistently has a poor prognosis in breast cancer. Therefore, we thoroughly investigated the biological processes of NEK2 and the regulation of NEK2 with miRNA.

Results of the GO analysis revealed a significant presence of NEK gene family members in the development of breast cancer. The GO analysis of genes co-expressed with NEK2 from the METABRIC and TCGA datasets showed that almost all of them were associated with cell division and DNA replication in BPs [102,103], ATPase activity in MFs [104-107], chromosomal regions in CCs [108], and cell cycles and oocyte meiosis in KEGG [109-111]. The study revealed the involvement of DEGs with GO terms of BPs and KEGG. PKMYT1, KIF4A, and CDC25C were associated with GO in terms of BPs; previous studies also revealed the overexpression of these genes in breast cancer [112-114]. PKMYT1, MYBL2, and CDC20 participate in GO terms of the most upregulated KEGG processes and are involved in the development of breast cancer [113,115-117]. The GSEA result also revealed that the high expression of NEK2 groups in the TCGA breast cancer database were significantly correlated with G2M checkpoint, E2F, MYC targets signaling 
pathways [118-120]. An investigative analysis of the network interaction between NEK2 and miRNA revealed hsa-miR-1236-3p, hsa-miR-4264, hsa-miR-486-5p, hsa-miR-155-3p, and hsa-miR-6839-3p are co-expressed for breast cancer development. In a recent study, the miRNA hsa-miR-1236-3p was identified as having overexpression at the TNM stage and metastases of colon cancer [121]. Meanwhile, hsa-miR-486-5p has been identified as a prognostic biomarker and therapeutic target in lung cancer [122]. The results of miRNA investigations in this study are also consistent with previous studies that found the involvement of hsa-miR-155-3p in breast cancer [123].

The MetaCore results of this study revealed a high correlation between NEK2 and the cell cycle and metaphase checkpoint pathway in breast cancer development [124-126]. This pathway was associated with several genes, including CDCA1, CDC20, MAD2a, PLK1, Aurora-A, BUB1, and BUBR1 (Supplementary Table S3, Figure 8). Meanwhile, PLK1 overexpressed in the liver, lung, stomach, and epidermis [127], BUBR1 (also known as homologue beta) is overexpressed in colorectal cancer, lung, pancreatic tumors, and Tcell lymphoma [128,129]. Cell cycle regulation of protein kinases plays a significant and potentially exciting role in cancer therapeutics [130]. In cell cycle kinases in human cancers, previous studies have revealed that Aurora-A is overexpressed in several human tumors, including breast, colorectal, and bladder cancers [131,132].

A previous study demonstrated the critical roles of cell-cycle checkpoint processes and DNA repair in cancer development because of their respective functions in regulating genome stability and cell development [133]. Furthermore, cell-cycle checkpoints have the potential to significantly improve cancer treatments [118]. Our data also revealed that NEK family genes were correlated with cell cycle regulation. However, since data of the study were acquired only by performing integrated bioinformatics analyses, further in vitro and in vivo experiments should be designed, because these current findings provide clearer insights into the functions of NEK family genes in breast cancer. This will definitely improve the treatment and management of breast cancer patients [134-138].

Finally, we identified NEK2 as a potential biomarker of immune cells in breast cancer tissues. We discovered the correlation between the NEK2 gene's expression and immunological levels of $\mathrm{B}$ cells, $\mathrm{CD} 4^{+} \mathrm{T}$ cells, neutrophils, and DCs. These findings are consistent with current research, revealing that $B$ cells provide a potential target for cancer intervention $[139,140]$. Previous studies have also shown that $\mathrm{CD}^{+} \mathrm{T}$ cells significantly inhibit tumor development [141], neutrophils [142-144], and DCs [145-148], and our study also revealed correlations of the NEK2 gene with several immune infiltration rate algorithms in breast cancer tissues. We found high correlations of NEK2 gene expression with B cell and T cell, $\mathrm{CD}^{+} \mathrm{Th} 2$ cell. Another interesting finding in this study is the link between NEK2 BPs and immunological categories in the GSEA analysis. We found that NEK2 was correlated with hallmark interferon-alpha and gamma responses $\left(p=1.54 \times 10^{-4}\right.$, NES $=1.78)$ and $\left(p=8.48 \times 10^{-3}, \mathrm{NES}=1.4\right)$, respectively (Supplementary Table S2, Figure 7B). Interestingly, these findings are consistent with previous studies, which suggested that interferon regulators play an essential role in developing anti-tumor immunity and post-chemotherapy metastasis-free survival of triple-negative breast cancer (TNBC) [149]. In addition, previous studies have also reported a correlation between interferon regulation and T cell signature $[150,151]$. Therefore, NEK2 has the potential as a prognostic biomarker for immune infiltration in breast cancer development.

\section{Conclusions}

Our study revealed that among all members of the NEK family, NEK2 is overexpressed in breast cancer patients and is associated with a poor prognosis in breast cancer. On the enrichment pathway, we also discovered an important role of NEK2 on the cell cycle and metaphase checkpoint regulation. In conclusion, NEK2 may have potential value as a prognostic and immune infiltration marker for breast cancer development. 
Supplementary Materials: The following are available online at https:/ / www.mdpi.com/article/10.3 390/jpm11111089/s1, Figure S1: Heatmap of DNA methylation expression levels of the NEK gene family in breast cancer by MethSurv platform. cg02998883, cg05110629, cg26722769 of NEK1; cg15831905, cg17931972 of NEK2; cg19524009, cg22056112 of NEK3; cg02636488 of NEK4; cg15721359, cg18615369 of NEK5; cg14536906, cg13866149, cg13974765, cg14289738 of NEK6; cg04223956, cg09372617 of NEK7; cg17742559 of NEK8; cg04246305 of NEK9; cg09642369, cg17918906 of NEK10; cg01378599, cg06239593 of NEK11 displays the highest level of DNA methylation in breast cancer. Table S1: Prognostic Value of Single CpG of the NEK gene family in breast cancer by MethSurv platform. The threshold of significance was LR Test $p$-value $<0.05$. A significant expression pattern was found in NEK $2 / 6$ between low and high risk groups for breast cancer. Table S2: Hallmark signaling pathway analysis of NEK2 in BRCA (GSEA Analysis). Table S3: Pathway analysis of genes coexpressed NEK2 from public breast cancer databases using the MetaCore database (with $p$-value $<0.05$ set as the cutoff value). Figure S2: Analysis of micro (mi)RNA networks with NEK2 in breast cancer. We used the miRWalk database to identify associations with NEK2, and then network regulation was analyzed by Ingenuity Pathway Analysis (IPA). hsa-miR-1236-3p, hsa-miR-4264, hsa-miR-486-5p, hsa-miR-155-3p, and hsa-miR-6839-3p are co-expressed for breast cancer development. Table S4: Correlation of NEK2 expression with the level of immune infiltration of B cells in BRCA (Analysis of TIMER database). The data shows the partial correlation value, and the level of statistical significance is shown with $p$-value and adjusted $p$-value. The threshold of significance was $p$-value $<0.05$. Figure S3: Heatmap of NEK2 expression with the level of immune infiltration of B cells in different types of cancer (Analysis of TIMER database). The partial correlation coefficient shows the size of the correlation, and the $p$-value indicates the level of statistical significance. The threshold of significance was $p$-value $<0.05$. Table S5: Correlation of NEK2 expression with the level of immune infiltration of CD4+ T Cells in BRCA (Analysis of TIMER database). rho shows the partial correlation value, and the level of statistical significance is shown with $p$-value and adjusted $p$-value. The threshold of significance was $p$-value $<0.05$. Figure S4: Heatmap of NEK2 expression with the level of immune infiltration of CD4+ $\mathrm{T}$ Cells in different types of cancer (Analysis of TIMER database). The partial correlation coefficient shows the size of the correlation, and the $p$-value indicates the level of statistical significance. The threshold of significance was $p$-value $<0.05$.

Author Contributions: G.A., W.-J.W., F.B.P., H.D.K.T., D.T.M.X., V.A., M.A., Y.-F.W. and S.-C.K. conceived the project, performed the bioinformatics analysis, and wrote the manuscript., and N.N.P. and N.T.A.T. were responsible for manuscript editing. C.-Y.W., and K.-H.L. performed the data analysis and revised the manuscript. All authors have read and agreed to the published version of the manuscript.

Funding: The study was supported by grants from Taipei Medical University (grant TMU-108-AE1B16 to C.-Y.W.), and the Ministry of Science and Technology (MOST) of Taiwan (MOST109-2320-B-038009-MY2 to C-Y.W. and MOST-109-2320-B-039 -003-MY2 and MOST-110-2320-B-039-068 to W-J.W.), China Medical University (CMU109-MF-55 to W-J.W.), the Ministry Health and Welfare Surcharge of Education Tobacco Products of Taiwan (Wan-Fang Hospital, Chi-Mei Medical Center, and Hualien Tzu-Chi Hospital Joint Cancer Center Grant-Focus on Colon Cancer Research; grant no.: MOHW110TDU-B-212-144020, awarded to K.-H.L.), Ministry of Education of Taiwan (grant no.: DP2-110-2112103-C-03-03), and the "TMU Research Center of Cancer Translational Medicine" from The Featured Areas Research Center Program within the framework of the Higher Education Sprout Project by the Ministry of Education (MOE) in Taiwan.

Institutional Review Board Statement: Not applicable.

Informed Consent Statement: Not applicable.

Data Availability Statement: The datasets used and/or analyzed during the current study are available from the corresponding author upon reasonable request.

Acknowledgments: We thank the staff of the Clinical Data Center, Office of Data Science, Taipei Medical University, Taiwan, for technical support. Meanwhile, The authors give special thanks to Daniel P. Chamberlin for his professional English editing.

Conflicts of Interest: The authors declare no conflict of interest. 


\section{References}

1. Sung, H.; Ferlay, J.; Siegel, R.L.; Laversanne, M.; Soerjomataram, I.; Jemal, A.; Bray, F. Global Cancer Statistics 2020: GLOBOCAN Estimates of Incidence and Mortality Worldwide for 36 Cancers in 185 Countries. CA Cancer J. Clin. 2021, 71, 209-249. [CrossRef]

2. Koboldt, D.C.; Fulton, R.S.; McLellan, M.D.; Schmidt, H.; Kalicki-Veizer, J.; McMichael, J.F.; Fulton, L.L.; Dooling, D.J.; Ding, L.; Mardis, E.R.; et al. Comprehensive molecular portraits of human breast tumours. Nature 2012, 490, 61-70. [CrossRef]

3. Lin, C.-Y.; Lee, C.-H.; Chuang, Y.-H.; Lee, J.-Y.; Chiu, Y.-Y.; Wu Lee, Y.-H.; Jong, Y.-J.; Hwang, J.-K.; Huang, S.-H.; Chen, L.-C.; et al. Membrane protein-regulated networks across human cancers. Nat. Commun. 2019, 10, 3131. [CrossRef]

4. Tsai, H.-T.; Huang, C.-S.; Tu, C.-C.; Liu, C.-Y.; Huang, C.-J.; Ho, Y.-S.; Tu, S.-H.; Tseng, L.-M.; Huang, C.-C. Multi-gene signature of microcalcification and risk prediction among Taiwanese breast cancer. Sci. Rep. 2020, 10, 18276. [CrossRef]

5. Nguyen, H.D.; Liao, Y.C.; Ho, Y.S.; Chen, L.C.; Chang, H.W.; Cheng, T.C.; Liu, D.; Lee, W.R.; Shen, S.C.; Wu, C.H.; et al. The alpha9 Nicotinic Acetylcholine Receptor Mediates Nicotine-Induced PD-L1 Expression and Regulates Melanoma Cell Proliferation and Migration. Cancers 2019, 11, 1991. [CrossRef]

6. Lee, K.L.; Kuo, Y.C.; Ho, Y.S.; Huang, Y.H. Triple-Negative Breast Cancer: Current Understanding and Future Therapeutic Breakthrough Targeting Cancer Stemness. Cancers 2019, 11, 1334. [CrossRef] [PubMed]

7. Marczyk, M.; Polańska, J.; Wojcik, A.; Lundholm, L. Analysis of the Applicability of microRNAs in Peripheral Blood Leukocytes as Biomarkers of Sensitivity and Exposure to Fractionated Radiotherapy towards Breast Cancer. Int. J. Mol. Sci. 2021, $22,8705$. [CrossRef]

8. Marczyk, M.; Patwardhan, G.A.; Zhao, J.; Qu, R.; Li, X.; Wali, V.B.; Gupta, A.K.; Pillai, M.M.; Kluger, Y.; Yan, Q.; et al. Multi-Omics Investigation of Innate Navitoclax Resistance in Triple-Negative Breast Cancer Cells. Cancers 2020, 12, 2551. [CrossRef] [PubMed]

9. Drobin, K.; Marczyk, M.; Halle, M.; Danielsson, D.; Papiez, A.; Sangsuwan, T.; Bendes, A.; Hong, M.G.; Qundos, U.; HarmsRingdahl, M.; et al. Molecular Profiling for Predictors of Radiosensitivity in Patients with Breast or Head-and-Neck Cancer. Cancers 2020, 12, 753. [CrossRef] [PubMed]

10. Madsen, R.R.; Longden, J.; Knox, R.G.; Robin, X.; Völlmy, F.; Macleod, K.G.; Moniz, L.S.; Carragher, N.O.; Linding, R.; Vanhaesebroeck, B.; et al. NODAL/TGF $\beta$ signalling mediates the self-sustained stemness induced by PIK3CA (H1047R) homozygosity in pluripotent stem cells. Dis. Model. Mech. 2021, 14, 3. [CrossRef] [PubMed]

11. Berenjeno, I.M.; Piñeiro, R.; Castillo, S.D.; Pearce, W.; McGranahan, N.; Dewhurst, S.M.; Meniel, V.; Birkbak, N.J.; Lau, E.; Sansregret, L.; et al. Oncogenic PIK3CA induces centrosome amplification and tolerance to genome doubling. Nat. Commun. 2017, 8, 1773. [CrossRef]

12. Alliouachene, S.; Bilanges, B.; Chaussade, C.; Pearce, W.; Foukas, L.C.; Scudamore, C.L.; Moniz, L.S.; Vanhaesebroeck, B. Inactivation of class II PI3K-C2 $\alpha$ induces leptin resistance, age-dependent insulin resistance and obesity in male mice. Diabetologia 2016, 59, 1503-1512. [CrossRef]

13. Moniz, L.; Dutt, P.; Haider, N.; Stambolic, V. Nek family of kinases in cell cycle, checkpoint control and cancer. Cell Div. 2011, 6, 18. [CrossRef]

14. Manning, G.; Whyte, D.B.; Martinez, R.; Hunter, T.; Sudarsanam, S. The protein kinase complement of the human genome. Science 2002, 298, 1912-1934. [CrossRef] [PubMed]

15. O'Connell, M.J.; Krien, M.J.; Hunter, T. Never say never. The NIMA-related protein kinases in mitotic control. Trends Cell Biol. 2003, 13, 221-228. [CrossRef]

16. Pang, K.H.; Esperto, F.; Noon, A.P.; EAU Young Academic Urologists-Urothelial Cancer Working party. Opportunities of nextgeneration sequencing in non-muscle invasive bladder cancer outcome prediction. Transl. Urol. 2017, 6, 1043-1048. [CrossRef] [PubMed]

17. Cabral de Almeida Cardoso, L.; Rodriguez-Laguna, L.; Del Carmen Crespo, M.; Vallespin, E.; Palomares-Bralo, M.; Martin-Arenas, R.; Rueda-Arenas, I.; Silvestre de Faria, P.A.; Group, G.-C.W.; Garcia-Miguel, P.; et al. Array CGH Analysis of Paired Blood and Tumor Samples from Patients with Sporadic Wilms Tumor. PLoS ONE 2015, 10, e0136812. [CrossRef]

18. Dang, T.T.; Westcott, J.M.; Maine, E.A.; Kanchwala, M.; Xing, C.; Pearson, G.W. DeltaNp63alpha induces the expression of FAT2 and Slug to promote tumor invasion. Oncotarget 2016, 7, 28592-28611. [CrossRef]

19. Hayward, D.G.; Clarke, R.B.; Faragher, A.J.; Pillai, M.R.; Hagan, I.M.; Fry, A.M. The centrosomal kinase Nek2 displays elevated levels of protein expression in human breast cancer. Cancer Res. 2004, 64, 7370-7376. [CrossRef] [PubMed]

20. Miller, S.L.; DeMaria, J.E.; Freier, D.O.; Riegel, A.M.; Clevenger, C.V. Novel association of Vav2 and Nek3 modulates signaling through the human prolactin receptor. Mol. Endocrinol. 2005, 19, 939-949. [CrossRef] [PubMed]

21. Chen, Y.; Wu, N.; Liu, L.; Dong, H.; Liu, X. microRNA-128-3p overexpression inhibits breast cancer stem cell characteristics through suppression of Wnt signalling pathway by down-regulating NEK2. J. Cell Mol. Med. 2020, 24, 7353-7369. [CrossRef] [PubMed]

22. Pei, J.; Zhang, J.; Yang, X.; Wu, Z.; Sun, C.; Wang, Z.; Wang, B. NEK5 promotes breast cancer cell proliferation through up-regulation of Cyclin A2. Mol. Carcinog. 2019, 58, 933-943. [CrossRef] [PubMed]

23. Capra, M.; Nuciforo, P.G.; Confalonieri, S.; Quarto, M.; Bianchi, M.; Nebuloni, M.; Boldorini, R.; Pallotti, F.; Viale, G.; Gishizky, M.L.; et al. Frequent alterations in the expression of serine/threonine kinases in human cancers. Cancer Res. 2006, 66, 8147-8154. [CrossRef] [PubMed] 
24. Richards, M.W.; O’Regan, L.; Mas-Droux, C.; Blot, J.M.; Cheung, J.; Hoelder, S.; Fry, A.M.; Bayliss, R. An autoinhibitory tyrosine motif in the cell-cycle-regulated Nek7 kinase is released through binding of Nek9. Mol. Cell 2009, 36, 560-570. [CrossRef] [PubMed]

25. Bowers, A.J.; Boylan, J.F. Nek8, a NIMA family kinase member, is overexpressed in primary human breast tumors. Gene 2004, 328, 135-142. [CrossRef] [PubMed]

26. Antoniou, A.C.; Beesley, J.; McGuffog, L.; Sinilnikova, O.M.; Healey, S.; Neuhausen, S.L.; Ding, Y.C.; Rebbeck, T.R.; Weitzel, J.N.; Lynch, H.T.; et al. Common breast cancer susceptibility alleles and the risk of breast cancer for BRCA1 and BRCA2 mutation carriers: Implications for risk prediction. Cancer Res. 2010, 70, 9742-9754. [CrossRef] [PubMed]

27. Mulligan, A.M.; Couch, F.J.; Barrowdale, D.; Domchek, S.M.; Eccles, D.; Nevanlinna, H.; Ramus, S.J.; Robson, M.; Sherman, M.; Spurdle, A.B.; et al. Common breast cancer susceptibility alleles are associated with tumour subtypes in BRCA1 and BRCA2 mutation carriers: Results from the Consortium of Investigators of Modifiers of BRCA1/2. Breast Cancer Res. 2011, $13, \mathrm{R} 110$. [CrossRef]

28. Haider, N.; Dutt, P.; van de Kooij, B.; Ho, J.; Palomero, L.; Pujana, M.A.; Yaffe, M.; Stambolic, V. NEK10 tyrosine phosphorylates p53 and controls its transcriptional activity. Oncogene 2020, 39, 5252-5266. [CrossRef] [PubMed]

29. Sabir, S.R.; Sahota, N.K.; Jones, G.D.; Fry, A.M. Loss of Nek11 Prevents G2/M Arrest and Promotes Cell Death in HCT116 Colorectal Cancer Cells Exposed to Therapeutic DNA Damaging Agents. PLoS ONE 2015, 10, e0140975. [CrossRef]

30. Moniz, L.S.; Stambolic, V. Nek10 mediates G2/M cell cycle arrest and MEK autoactivation in response to UV irradiation. Mol. Cell Biol. 2011, 31, 30-42. [CrossRef] [PubMed]

31. Pavan, I.C.B.; Peres de Oliveira, A.; Dias, P.R.F.; Basei, F.L.; Issayama, L.K.; Ferezin, C.C.; Silva, F.R.; Rodrigues de Oliveira, A.L.; Alves Dos Reis Moura, L.; Martins, M.B.; et al. On Broken Ne(c)ks and Broken DNA: The Role of Human NEKs in the DNA Damage Response. Cells 2021, 10, 507. [CrossRef]

32. Schouten, P.C.; Richters, L.K.; Vis, D.J.; Kommoss, S.; van Dyk, E.; Ernst, C.; Kluin, R.J.C.; Marme, F.; Lips, E.H.; Schmidt, S.; et al. Ovarian cancer specific BRCA-like copy number aberration classifiers detect mutations associated with homologous recombination deficiency in the AGO-TR1 trial. Clin. Cancer Res. 2021, 21, 1673. [CrossRef]

33. Boussios, S.; Karathanasi, A.; Cooke, D.; Neille, C.; Sadauskaite, A.; Moschetta, M.; Zakynthinakis-Kyriakou, N.; Pavlidis, N. PARP Inhibitors in Ovarian Cancer: The Route to "Ithaca". Diagnostics 2019, 9, 55. [CrossRef] [PubMed]

34. Ioannidou, E.; Moschetta, M.; Shah, S.; Parker, J.S.; Ozturk, M.A.; Pappas-Gogos, G.; Sheriff, M.; Rassy, E.; Boussios, S. Angiogenesis and Anti-Angiogenic Treatment in Prostate Cancer: Mechanisms of Action and Molecular Targets. Int. J. Mol. Sci. 2021, 22, 9926. [CrossRef] [PubMed]

35. Revythis, A.; Shah, S.; Kutka, M.; Moschetta, M.; Ozturk, M.A.; Pappas-Gogos, G.; Ioannidou, E.; Sheriff, M.; Rassy, E.; Boussios, S. Unraveling the Wide Spectrum of Melanoma Biomarkers. Diagnostics 2021, 11, 1341. [CrossRef] [PubMed]

36. Saxby, H.; Mikropoulos, C.; Boussios, S. An Update on the Prognostic and Predictive Serum Biomarkers in Metastatic Prostate Cancer. Diagnostics 2020, 10, 549. [CrossRef]

37. Malumbres, M.; Barbacid, M. Cell cycle kinases in cancer. Curr. Opin. Genet. Dev. 2007, 17, 60-65. [CrossRef]

38. de Carcer, G.; Perez de Castro, I.; Malumbres, M. Targeting cell cycle kinases for cancer therapy. Curr. Med. Chem. 2007, 14, 969-985. [CrossRef]

39. Lin, J.C.; Liu, T.P.; Yang, P.M. CDKN2A-Inactivated Pancreatic Ductal Adenocarcinoma Exhibits Therapeutic Sensitivity to Paclitaxel: A Bioinformatics Study. J. Clin. Med. 2020, 9, 4019. [CrossRef]

40. Lin, T.Y.; Wang, P.W.; Huang, C.H.; Yang, P.M.; Pan, T.L. Characterizing the Relapse Potential in Different Luminal Subtypes of Breast Cancers with Functional Proteomics. Int. J. Mol. Sci. 2020, 21, 6077. [CrossRef]

41. Liu, L.W.; Hsieh, Y.Y.; Yang, P.M. Bioinformatics Data Mining Repurposes the JAK2 (Janus Kinase 2) Inhibitor Fedratinib for Treating Pancreatic Ductal Adenocarcinoma by Reversing the KRAS (Kirsten Rat Sarcoma 2 Viral Oncogene Homolog)-Driven Gene Signature. J. Pers. Med. 2020, 10, 130. [CrossRef] [PubMed]

42. Yang, P.M.; Hsieh, Y.Y.; Du, J.L.; Yen, S.C.; Hung, C.F. Sequential Interferon $\beta$-Cisplatin Treatment Enhances the Surface Exposure of Calreticulin in Cancer Cells via an Interferon Regulatory Factor 1-Dependent Manner. Biomolecules 2020, 10, 643. [CrossRef] [PubMed]

43. Yang, P.M.; Lin, L.S.; Liu, T.P. Sorafenib Inhibits Ribonucleotide Reductase Regulatory Subunit M2 (RRM2) in Hepatocellular Carcinoma Cells. Biomolecules 2020, 10, 117. [CrossRef]

44. Li, T.; Fan, J.; Wang, B.; Traugh, N.; Chen, Q.; Liu, J.S.; Li, B.; Liu, X.S. TIMER: A Web Server for Comprehensive Analysis of Tumor-Infiltrating Immune Cells. Cancer Res. 2017, 77, e108-e110. [CrossRef]

45. Li, B.; Severson, E.; Pignon, J.C.; Zhao, H.; Li, T.; Novak, J.; Jiang, P.; Shen, H.; Aster, J.C.; Rodig, S.; et al. Comprehensive analyses of tumor immunity: Implications for cancer immunotherapy. Genome Biol. 2016, 17, 174. [CrossRef]

46. Chandrashekar, D.S.; Bashel, B.; Balasubramanya, S.A.H.; Creighton, C.J.; Ponce-Rodriguez, I.; Chakravarthi, B.; Varambally, S. UALCAN: A Portal for Facilitating Tumor Subgroup Gene Expression and Survival Analyses. Neoplasia 2017, 19, 649-658. [CrossRef]

47. Cooke, D.L.; McCoy, D.B.; Halbach, V.V.; Hetts, S.W.; Amans, M.R.; Dowd, C.F.; Higashida, R.T.; Lawson, D.; Nelson, J.; Wang, C.Y.; et al. Endovascular Biopsy: In Vivo Cerebral Aneurysm Endothelial Cell Sampling and Gene Expression Analysis. Transl. Stroke Res. 2018, 9, 20-33. [CrossRef] 
48. Weng, T.Y.; Wu, H.F.; Li, C.Y.; Hung, Y.H.; Chang, Y.W.; Chen, Y.L.; Hsu, H.P.; Chen, Y.H.; Wang, C.Y.; Chang, J.Y.; et al. Homoharringtonine induced immune alteration for an Efficient Anti-tumor Response in Mouse Models of Non-small Cell Lung Adenocarcinoma Expressing Kras Mutation. Sci. Rep. 2018, 8, 8216. [CrossRef]

49. Wang, C.Y.; Li, C.Y.; Hsu, H.P.; Cho, C.Y.; Yen, M.C.; Weng, T.Y.; Chen, W.C.; Hung, Y.H.; Lee, K.T.; Hung, J.H.; et al. PSMB5 plays a dual role in cancer development and immunosuppression. Am. J. Cancer Res. 2017, 7, 2103-2120. [PubMed]

50. Lanczky, A.; Nagy, A.; Bottai, G.; Munkacsy, G.; Szabo, A.; Santarpia, L.; Gyorffy, B. miRpower: A web-tool to validate survivalassociated miRNAs utilizing expression data from 2178 breast cancer patients. Breast Cancer Res. Treat. 2016, 160, 439-446. [CrossRef]

51. Nagy, A.; Munkacsy, G.; Gyorffy, B. Pancancer survival analysis of cancer hallmark genes. Sci. Rep. 2021, 11, 6047. [CrossRef]

52. Wang, C.Y.; Chang, Y.C.; Kuo, Y.L.; Lee, K.T.; Chen, P.S.; Cheung, C.H.A.; Chang, C.P.; Phan, N.N.; Shen, M.R.; Hsu, H.P. Mutation of the PTCH1 gene predicts recurrence of breast cancer. Sci. Rep. 2019, 9, 16359. [CrossRef]

53. Cho, C.Y.; Lee, K.T.; Chen, W.C.; Wang, C.Y.; Chang, Y.S.; Huang, H.L.; Hsu, H.P.; Yen, M.C.; Lai, M.Z.; Lai, M.D. MST3 promotes proliferation and tumorigenicity through the VAV2/Rac1 signal axis in breast cancer. Oncotarget 2016, 7, 14586-14604. [CrossRef]

54. Huang, H.L.; Chen, W.C.; Hsu, H.P.; Cho, C.Y.; Hung, Y.H.; Wang, C.Y.; Lai, M.D. Argininosuccinate lyase is a potential therapeutic target in breast cancer. Oncol. Rep. 2015, 34, 3131-3139. [CrossRef] [PubMed]

55. Martens, J.W.; Margossian, A.L.; Schmitt, M.; Foekens, J.; Harbeck, N. DNA methylation as a biomarker in breast cancer. Future Oncol. 2009, 5, 1245-1256. [CrossRef] [PubMed]

56. Modhukur, V.; Iljasenko, T.; Metsalu, T.; Lokk, K.; Laisk-Podar, T.; Vilo, J. MethSurv: A web tool to perform multivariable survival analysis using DNA methylation data. Epigenomics 2018, 10, 277-288. [CrossRef]

57. Yu, G.; Wang, L.G.; Han, Y.; He, Q.Y. clusterProfiler: An R package for comparing biological themes among gene clusters. Omics 2012, 16, 284-287. [CrossRef]

58. Walter, W.; Sanchez-Cabo, F.; Ricote, M. GOplot: An R package for visually combining expression data with functional analysis. Bioinformatics 2015, 31, 2912-2914. [CrossRef]

59. Boyle, E.I.; Weng, S.; Gollub, J.; Jin, H.; Botstein, D.; Cherry, J.M.; Sherlock, G. GO:: TermFinder-open source software for accessing Gene Ontology information and finding significantly enriched Gene Ontology terms associated with a list of genes. Bioinformatics 2004, 20, 3710-3715. [CrossRef] [PubMed]

60. Sergushichev, A.A. An algorithm for fast preranked gene set enrichment analysis using cumulative statistic calculation. bioRxiv 2016. [CrossRef]

61. Korotkevich, G.; Sukhov, V.; Budin, N.; Shpak, B.; Artyomov, M.N.; Sergushichev, A. Fast gene set enrichment analysis. bioRxiv 2021. [CrossRef]

62. Hanahan, D.; Weinberg, R.A. Hallmarks of cancer: The next generation. Cell 2011, 144, 646-674. [CrossRef]

63. Damrauer, J.S.; Hoadley, K.A.; Chism, D.D.; Fan, C.; Tiganelli, C.J.; Wobker, S.E.; Yeh, J.J.; Milowsky, M.I.; Iyer, G.; Parker, J.S.; et al. Intrinsic subtypes of high-grade bladder cancer reflect the hallmarks of breast cancer biology. Proc. Natl. Acad. Sci. USA 2014, 111, 3110. [CrossRef]

64. Dai, X.; Xiang, L.; Li, T.; Bai, Z. Cancer Hallmarks, Biomarkers and Breast Cancer Molecular Subtypes. J. Cancer 2016, 7, 1281-1294. [CrossRef]

65. Cirillo, E.; Parnell, L.D.; Evelo, C.T. A Review of Pathway-Based Analysis Tools That Visualize Genetic Variants. Front. Genet. 2017, 8, 174. [CrossRef]

66. Yu, G.; Wang, W.; Wang, X.; Xu, M.; Zhang, L.; Ding, L.; Guo, R.; Shi, Y. Network pharmacology-based strategy to investigate pharmacological mechanisms of Zuojinwan for treatment of gastritis. BMC Complement. Altern Med. 2018, 18, 292. [CrossRef] [PubMed]

67. Shahi, P.; Wang, C.Y.; Lawson, D.A.; Slorach, E.M.; Lu, A.; Yu, Y.; Lai, M.D.; Gonzalez Velozo, H.; Werb, Z. ZNF503/Zpo2 drives aggressive breast cancer progression by down-regulation of GATA3 expression. Proc. Natl. Acad. Sci. USA 2017, 114, 3169-3174. [CrossRef] [PubMed]

68. Phan, N.N.; Wang, C.Y.; Lin, Y.C. The novel regulations of MEF2A, CAMKK2, CALM3, and TNNI3 in ventricular hypertrophy induced by arsenic exposure in rats. Toxicology 2014, 324, 123-135. [CrossRef]

69. Choy, T.K.; Wang, C.Y.; Phan, N.N.; Khoa Ta, H.D.; Anuraga, G.; Liu, Y.H.; Wu, Y.F.; Lee, K.H.; Chuang, J.Y.; Kao, T.J. Identification of Dipeptidyl Peptidase (DPP) Family Genes in Clinical Breast Cancer Patients via an Integrated Bioinformatics Approach. Diagnostics 2021, 11, 1204. [CrossRef]

70. Chen, P.S.; Hsu, H.P.; Phan, N.N.; Yen, M.C.; Chen, F.W.; Liu, Y.W.; Lin, F.P.; Feng, S.Y.; Cheng, T.L.; Yeh, P.H.; et al. CCDC167 as a potential therapeutic target and regulator of cell cycle-related networks in breast cancer. Aging (Albany NY) 2021, 13, 4157-4181. [CrossRef]

71. Bakre, A.; Andersen, L.E.; Meliopoulos, V.; Coleman, K.; Yan, X.; Brooks, P.; Crabtree, J.; Tompkins, S.M.; Tripp, R.A. Identification of Host Kinase Genes Required for Influenza Virus Replication and the Regulatory Role of MicroRNAs. PLoS ONE 2013, 8, e66796. [CrossRef]

72. Ting, G.; Li, X.; Kwon, H.Y.; Ding, T.; Zhang, Z.; Chen, Z.; Li, C.; Liu, Y.; Yang, Y. microRNA-219-5p targets NEK6 to inhibit hepatocellular carcinoma progression. Am. J. Transl. Res. 2020, 12, 7528-7541.

73. Falzone, L.; Grimaldi, M.; Celentano, E.; Augustin, L.S.A.; Libra, M. Identification of Modulated MicroRNAs Associated with Breast Cancer, Diet, and Physical Activity. Cancers 2020, 12, 2555. [CrossRef] 
74. Fujiwara, Y.; Saito, M.; Robles, A.I.; Nishida, M.; Takeshita, F.; Watanabe, M.; Ochiya, T.; Yokota, J.; Kohno, T.; Harris, C.C.; et al. A Nucleolar Stress-Specific p53-miR-101 Molecular Circuit Functions as an Intrinsic Tumor-Suppressor Network. EBioMedicine 2018, 33, 33-48. [CrossRef]

75. Frontiers Editorial, O. Retraction: Exosome-Derived miR-486-5p Regulates Cell Cycle, Proliferation and Metastasis in Lung Adenocarcinoma via Targeting NEK2. Front. Bioeng. Biotechnol. 2021, 9, 681918. [CrossRef]

76. Luo, M.; Zeng, H.; Ma, X.Y.; Ma, X.L. Identification of Hub Genes for Ovarian Cancer Stem Cell Properties with Weighted Gene Co-expression Network Analysis. Sichuan Da Xue Xue Bao Yi Xue Ban 2021, 52, 248-258. [CrossRef]

77. de Almeida, B.P.; Apolónio, J.D.; Binnie, A.; Castelo-Branco, P. Roadmap of DNA methylation in breast cancer identifies novel prognostic biomarkers. BMC Cancer 2019, 19, 219. [CrossRef]

78. Pouliot, M.C.; Labrie, Y.; Diorio, C.; Durocher, F. The Role of Methylation in Breast Cancer Susceptibility and Treatment. Anticancer Res. 2015, 35, 4569-4574. [PubMed]

79. Garaud, S.; Buisseret, L.; Solinas, C.; Gu-Trantien, C.; de Wind, A.; Van den Eynden, G.; Naveaux, C.; Lodewyckx, J.N.; Boisson, A.; Duvillier, H.; et al. Tumor infiltrating B-cells signal functional humoral immune responses in breast cancer. JCI Insight 2019, 5, 18. [CrossRef]

80. Disis, M.L.; Stanton, S.E. Triple-Negative Breast Cancer: Immune Modulation as the New Treatment Paradigm. Am. Soc. Clin. Oncol. Educ. Book 2015, 35, e25-e30. [CrossRef]

81. Kuroda, H.; Jamiyan, T.; Yamaguchi, R.; Kakumoto, A.; Abe, A.; Harada, O.; Masunaga, A. Tumor-infiltrating B cells and T cells correlate with postoperative prognosis in triple-negative carcinoma of the breast. BMC Cancer 2021, 21, 286. [CrossRef]

82. Melo-Hanchuk, T.D.; Martins, M.B.; Cunha, L.L.; Soares, F.A.; Ward, L.S.; Vassallo, J.; Kobarg, J. Expression of the NEK family in normal and cancer tissue: An immunohistochemical study. BMC Cancer 2020, 20, 23. [CrossRef]

83. Peres de Oliveira, A.; Kazuo Issayama, L.; Betim Pavan, I.C.; Riback Silva, F.; Diniz Melo-Hanchuk, T.; Moreira Simabuco, F.; Kobarg, J. Checking NEKs: Overcoming a Bottleneck in Human Diseases. Molecules 2020, 25, 1778. [CrossRef]

84. Basei, F.L.; Meirelles, G.V.; Righetto, G.L.; Dos Santos Migueleti, D.L.; Smetana, J.H.; Kobarg, J. New interaction partners for Nek4.1 and Nek4.2 isoforms: From the DNA damage response to RNA splicing. Proteome Sci. 2015, 13, 11. [CrossRef]

85. Melo Hanchuk, T.D.; Papa, P.F.; La Guardia, P.G.; Vercesi, A.E.; Kobarg, J. Nek5 interacts with mitochondrial proteins and interferes negatively in mitochondrial mediated cell death and respiration. Cell Signal. 2015, 27, 1168-1177. [CrossRef]

86. Ino, Y.; Yamazaki-Itoh, R.; Shimada, K.; Iwasaki, M.; Kosuge, T.; Kanai, Y.; Hiraoka, N. Immune cell infiltration as an indicator of the immune microenvironment of pancreatic cancer. Br. J. Cancer 2013, 108, 914-923. [CrossRef]

87. Wang, S.; Zhang, Q.; Yu, C.; Cao, Y.; Zuo, Y.; Yang, L. Immune cell infiltration-based signature for prognosis and immunogenomic analysis in breast cancer. Brief. Bioinform. 2021, 22, 2020-2031. [CrossRef]

88. Lv, Y.; Lv, D.; Lv, X.; Xing, P.; Zhang, J.; Zhang, Y. Immune Cell Infiltration-Based Characterization of Triple-Negative Breast Cancer Predicts Prognosis and Chemotherapy Response Markers. Front. Genet. 2021, 12, 354. [CrossRef]

89. Longo, V.; Longo, A.; Adamo, G.; Fiannaca, A.; Picciotto, S.; La Paglia, L.; Romancino, D.; La Rosa, M.; Urso, A.; Cibella, F.; et al. 2,2' 4,4'-Tetrabromodiphenyl Ether (PBDE-47) Modulates the Intracellular miRNA Profile, sEV Biogenesis and Their miRNA Cargo Exacerbating the LPS-Induced Pro-Inflammatory Response in THP-1 Macrophages. Front. Immunol. 2021, $12,664534$. [CrossRef] [PubMed]

90. Fiannaca, A.; La Rosa, M.; Urso, A.; Rizzo, R.; Gaglio, S. A knowledge-based decision support system in bioinformatics: An application to protein complex extraction. BMC Bioinform. 2013, 14, S5. [CrossRef]

91. Wang, J.; Chen, J.; Sen, S. MicroRNA as Biomarkers and Diagnostics. J. Cell. Physiol. 2016, 231, 25-30. [CrossRef]

92. Graveel, C.R.; Calderone, H.M.; Westerhuis, J.J.; Winn, M.E.; Sempere, L.F. Critical analysis of the potential for microRNA biomarkers in breast cancer management. Breast Cancer 2015, 7, 59-79. [CrossRef] [PubMed]

93. Jiang, N.; Zhang, X.; Qin, D.; Yang, J.; Wu, A.; Wang, L.; Sun, Y.; Li, H.; Shen, X.; Lin, J.; et al. Identification of Core Genes Related to Progression and Prognosis of Hepatocellular Carcinoma and Small-Molecule Drug Predication. Front. Genet. 2021, $12,608017$. [CrossRef] [PubMed]

94. Rivera-Rivera, Y.; Marina, M.; Jusino, S.; Lee, M.; Velazquez, J.V.; Chardon-Colon, C.; Vargas, G.; Padmanabhan, J.; Chellappan, S.P.; Saavedra, H.I. The Nek2 centrosome-mitotic kinase contributes to the mesenchymal state, cell invasion, and migration of triple-negative breast cancer cells. Sci. Rep. 2021, 11, 9016. [CrossRef] [PubMed]

95. Ghose, A.; Moschetta, M.; Pappas-Gogos, G.; Sheriff, M.; Boussios, S. Genetic Aberrations of DNA Repair Pathways in Prostate Cancer: Translation to the Clinic. Int. J. Mol. Sci. 2021, 22, 9783. [CrossRef]

96. Chen, F.; Feng, Z.; Zhu, J.; Liu, P.; Yang, C.; Huang, R.; Deng, Z. Emerging roles of circRNA_NEK6 targeting miR-370-3p in the proliferation and invasion of thyroid cancer via Wnt signaling pathway. Cancer Biol. 2018, 19, 1139-1152. [CrossRef]

97. Orenay-Boyacioglu, S.; Kasap, E.; Gerceker, E.; Yuceyar, H.; Demirci, U.; Bilgic, F.; Korkmaz, M. Expression profiles of histone modification genes in gastric cancer progression. Mol. Biol. Rep. 2018, 45, 2275-2282. [CrossRef] [PubMed]

98. Cao, X.; Xia, Y.; Yang, J.; Jiang, J.; Chen, L.; Ni, R.; Li, L.; Gu, Z. Clinical and biological significance of never in mitosis gene A-related kinase 6 (NEK6) expression in hepatic cell cancer. Pathol. Oncol. Res. 2012, 18, 201-207. [CrossRef]

99. He, Z.; Ni, X.; Xia, L.; Shao, Z. Overexpression of NIMA-related kinase 6 (NEK6) contributes to malignant growth and dismal prognosis in Human Breast Cancer. Pathol. Res. Pract. 2018, 214, 1648-1654. [CrossRef]

100. Ding, X.F.; Chen, J.; Zhou, J.; Chen, G.; Wu, Y.L. Never-in-mitosis A-related kinase 8, a novel target of von-Hippel-Lindau tumor suppressor protein, promotes gastric cancer cell proliferation. Oncol. Lett. 2018, 16, 5900-5906. [CrossRef] [PubMed] 
101. Liu, X.; Gao, Y.; Lu, Y.; Zhang, J.; Li, L.; Yin, F. Downregulation of NEK11 is associated with drug resistance in ovarian cancer. Int. J. Oncol. 2014, 45, 1266-1274. [CrossRef] [PubMed]

102. Vassilev, A.; DePamphilis, M.L. Links between DNA Replication, Stem Cells and Cancer. Genes 2017, 8, 45. [CrossRef] [PubMed]

103. Sun, Y.; Liu, Y.; Ma, X.; Hu, H. The Influence of Cell Cycle Regulation on Chemotherapy. Int. J. Mol. Sci. 2021, 22, 6923. [CrossRef]

104. Pirali, M.; Taheri, M.; Zarei, S.; Majidi, M.; Ghafouri, H. Artesunate, as a HSP70 ATPase activity inhibitor, induces apoptosis in breast cancer cells. Int. J. Biol. Macromol. 2020, 164, 3369-3375. [CrossRef]

105. Khajah, M.A.; Mathew, P.M.; Luqmani, Y.A. Na+/K+ ATPase activity promotes invasion of endocrine resistant breast cancer cells. PLoS ONE 2018, 13, e0193779. [CrossRef] [PubMed]

106. Mohammad, A.H.; Kim, S.-H.; Bertos, N.; El-Assaad, W.; Nandi, I.; Smith, H.; Yang, J.; Chen, O.J.; Gamache, I.; Rao, T.; et al. Elevated V-ATPase Activity Following PTEN Loss Is Required for Enhanced Oncogenic Signaling in Breast Cancer. Mol. Cancer Res. 2020, 18, 1477. [CrossRef] [PubMed]

107. De Luca, M.; Romano, R.; Bucci, C. Role of the V1G1 subunit of V-ATPase in breast cancer cell migration. Sci. Rep. 2021, 11, 4615. [CrossRef]

108. Yu, W.; Kanaan, Y.; Bae, Y.K.; Gabrielson, E. Chromosomal changes in aggressive breast cancers with basal-like features. Cancer Genet. Cytogenet. 2009, 193, 29-37. [CrossRef]

109. Fry, A.M.; O’Regan, L.; Sabir, S.R.; Bayliss, R. Cell cycle regulation by the NEK family of protein kinases. J. Cell Sci. 2012, 125, 4423-4433. [CrossRef] [PubMed]

110. Wu, D.; Han, B.; Guo, L.; Fan, Z. Molecular mechanisms associated with breast cancer based on integrated gene expression profiling by bioinformatics analysis. J. Obs. Gynaecol. 2016, 36, 615-621. [CrossRef] [PubMed]

111. Liu, H.; Ye, H. Screening of the prognostic targets for breast cancer based co-expression modules analysis. Mol. Med. Rep. 2017, 16, 4038-4044. [CrossRef]

112. Xue, D.; Cheng, P.; Han, M.; Liu, X.; Xue, L.; Ye, C.; Wang, K.; Huang, J. An integrated bioinformatical analysis to evaluate the role of KIF4A as a prognostic biomarker for breast cancer. OncoTargets Ther. 2018, 11, 4755-4768. [CrossRef]

113. Liu, Y.; Qi, J.; Dou, Z.; Hu, J.; Lu, L.; Dai, H.; Wang, H.; Yang, W. Systematic expression analysis of WEE family kinases reveals the importance of PKMYT1 in breast carcinogenesis. Cell Prolif. 2020, 53, e12741. [CrossRef] [PubMed]

114. Wang, H.; Lu, C.; Li, Q.; Xie, J.; Chen, T.; Tan, Y.; Wu, C.; Jiang, J. The role of Kif4A in doxorubicin-induced apoptosis in breast cancer cells. Mol. Cells 2014, 37, 812-818. [CrossRef]

115. Bayley, R.; Ward, C.; Garcia, P. MYBL2 amplification in breast cancer: Molecular mechanisms and therapeutic potential. Biochim. Biophys. Acta Rev. Cancer 2020, 1874, 188407. [CrossRef]

116. Chen, J.; Chen, X. MYBL2 Is Targeted by miR-143-3p and Regulates Breast Cancer Cell Proliferation and Apoptosis. Oncol. Res. 2018, 26, 913-922. [CrossRef] [PubMed]

117. Wang, L.; Zhang, J.; Wan, L.; Zhou, X.; Wang, Z.; Wei, W. Targeting Cdc20 as a novel cancer therapeutic strategy. Pharm. Ther. 2015, 151, 141-151. [CrossRef] [PubMed]

118. Visconti, R.; Della Monica, R.; Grieco, D. Cell cycle checkpoint in cancer: A therapeutically targetable double-edged sword. J. Exp. Clin. Cancer Res. 2016, 35, 153. [CrossRef] [PubMed]

119. Bièche, I.; Vacher, S.; Lallemand, F.; Tozlu-Kara, S.; Bennani, H.; Beuzelin, M.; Driouch, K.; Rouleau, E.; Lerebours, F.; Ripoche, H.; et al. Expression analysis of mitotic spindle checkpoint genes in breast carcinoma: Role of NDC80/HEC1 in early breast tumorigenicity, and a two-gene signature for aneuploidy. Mol. Cancer 2011, 10, 23. [CrossRef]

120. Lee, H.; Trainer, A.H.; Friedman, L.S.; Thistlethwaite, F.C.; Evans, M.J.; Ponder, B.A.J.; Venkitaraman, A.R. Mitotic Checkpoint Inactivation Fosters Transformation in Cells Lacking the Breast Cancer Susceptibility Gene, Brca2. Mol. Cell 1999, 4, 1-10. [CrossRef]

121. Zhao, Y.; Zhou, H.; Shen, J.; Yang, S.; Deng, K.; Li, Q.; Cui, W. MiR-1236-3p Inhibits the Proliferation, Invasion, and Migration of Colon Cancer Cells and Hinders Epithelial-Mesenchymal Transition by Targeting DCLK3. Front. Oncol. 2021, 11, 688882. [CrossRef] [PubMed]

122. Tian, F.; Wang, J.; Ouyang, T.; Lu, N.; Lu, J.; Shen, Y.; Bai, Y.; Xie, X.; Ge, Q. MiR-486-5p Serves as a Good Biomarker in Nonsmall Cell Lung Cancer and Suppresses Cell Growth with the Involvement of a Target PIK3R1. Front. Genet. 2019, 10, 688. [CrossRef] [PubMed]

123. Zhang, L.; Chen, T.; Yan, L.; Xu, H.; Wang, Y.; Li, Y.; Wang, H.; Chen, S.; Wang, W.; Chen, C.; et al. MiR-155-3p acts as a tumor suppressor and reverses paclitaxel resistance via negative regulation of MYD88 in human breast cancer. Gene 2019, 700, 85-95. [CrossRef]

124. Bower, J.J.; Vance, L.D.; Psioda, M.; Smith-Roe, S.L.; Simpson, D.A.; Ibrahim, J.G.; Hoadley, K.A.; Perou, C.M.; Kaufmann, W.K. Patterns of cell cycle checkpoint deregulation associated with intrinsic molecular subtypes of human breast cancer cells. NPJ Breast Cancer 2017, 3, 9. [CrossRef]

125. Thu, K.L.; Soria-Bretones, I.; Mak, T.W.; Cescon, D.W. Targeting the cell cycle in breast cancer: Towards the next phase. Cell Cycle 2018, 17, 1871-1885. [CrossRef]

126. Tenga, M.J.; Lazar, I.M. Proteomic snapshot of breast cancer cell cycle: G1/S transition point. Proteomics 2013, 13, 48-60. [CrossRef] [PubMed]

127. Simizu, S.; Osada, H. Mutations in the Plk gene lead to instability of Plk protein in human tumour cell lines. Nat. Cell Biol. 2000, 2, 852-854. [CrossRef] [PubMed] 
128. Kops, G.J.P.L.; Weaver, B.A.A.; Cleveland, D.W. On the road to cancer: Aneuploidy and the mitotic checkpoint. Nat. Rev. Cancer 2005, 5, 773-785. [CrossRef] [PubMed]

129. Matsuura, S.; Matsumoto, Y.; Morishima, K.; Izumi, H.; Matsumoto, H.; Ito, E.; Tsutsui, K.; Kobayashi, J.; Tauchi, H.; Kajiwara, Y.; et al. Monoallelic BUB1B mutations and defective mitotic-spindle checkpoint in seven families with premature chromatid separation (PCS) syndrome. Am. J. Med. Genet. A 2006, 140, 358-367. [CrossRef] [PubMed]

130. Lapenna, S.; Giordano, A. Cell cycle kinases as therapeutic targets for cancer. Nat. Rev. Drug Discov. 2009, 8, 547-566. [CrossRef]

131. Barr, A.R.; Gergely, F. Aurora-A: The maker and breaker of spindle poles. J. Cell Sci. 2007, 120, 2987-2996. [CrossRef] [PubMed]

132. Pérez de Castro, I.; de Cárcer, G.; Malumbres, M. A census of mitotic cancer genes: New insights into tumor cell biology and cancer therapy. Carcinogenesis 2007, 28, 899-912. [CrossRef] [PubMed]

133. Kastan, M.B.; Bartek, J. Cell-cycle checkpoints and cancer. Nature 2004, 432, 316-323. [CrossRef] [PubMed]

134. Abrams, S.L.; Akula, S.M.; Meher, A.K.; Steelman, L.S.; Gizak, A.; Duda, P.; Rakus, D.; Martelli, A.M.; Ratti, S.; Cocco, L.; et al. GSK-3 $\beta$ Can Regulate the Sensitivity of MIA-PaCa-2 Pancreatic and MCF-7 Breast Cancer Cells to Chemotherapeutic Drugs, Targeted Therapeutics and Nutraceuticals. Cells 2021, 10, 816. [CrossRef]

135. Candido, S.; Tomasello, B.M.R.; Lavoro, A.; Falzone, L.; Gattuso, G.; Libra, M. Novel Insights into Epigenetic Regulation of IL6 Pathway: In Silico Perspective on Inflammation and Cancer Relationship. Int. J. Mol. Sci. 2021, 22, 10172. [CrossRef]

136. Vivarelli, S.; Falzone, L.; Candido, S.; Bonavida, B.; Libra, M. YY1 Silencing Induces 5-Fluorouracil-Resistance and BCL2L15 Downregulation in Colorectal Cancer Cells: Diagnostic and Prognostic Relevance. Int. J. Mol. Sci. 2021, 22, 8481. [CrossRef] [PubMed]

137. Vivarelli, S.; Candido, S.; Caruso, G.; Falzone, L.; Libra, M. Patient-Derived Tumor Organoids for Drug Repositioning in Cancer Care: A Promising Approach in the Era of Tailored Treatment. Cancers 2020, 12, 3636. [CrossRef] [PubMed]

138. Crimi, S.; Falzone, L.; Gattuso, G.; Grillo, C.M.; Candido, S.; Bianchi, A.; Libra, M. Droplet Digital PCR Analysis of Liquid Biopsy Samples Unveils the Diagnostic Role of hsa-miR-133a-3p and hsa-miR-375-3p in Oral Cancer. Biology 2020, 9, 379. [CrossRef]

139. Gu, Y.; Liu, Y.; Fu, L.; Zhai, L.; Zhu, J.; Han, Y.; Jiang, Y.; Zhang, Y.; Zhang, P.; Jiang, Z.; et al. Tumor-educated B cells selectively promote breast cancer lymph node metastasis by HSPA4-targeting IgG. Nat. Med. 2019, 25, 312-322. [CrossRef] [PubMed]

140. Hu, Q.; Hong, Y.; Qi, P.; Lu, G.; Mai, X.; Xu, S.; He, X.; Guo, Y.; Gao, L.; Jing, Z.; et al. Atlas of breast cancer infiltrated B-lymphocytes revealed by paired single-cell RNA-sequencing and antigen receptor profiling. Nat. Commun. 2021, $12,2186$. [CrossRef] [PubMed]

141. Su, S.; Liao, J.; Liu, J.; Huang, D.; He, C.; Chen, F.; Yang, L.; Wu, W.; Chen, J.; Lin, L.; et al. Blocking the recruitment of naive CD4(+) T cells reverses immunosuppression in breast cancer. Cell Res. 2017, 27, 461-482. [CrossRef]

142. Wu, L.; Saxena, S.; Goel, P.; Prajapati, D.R.; Wang, C.; Singh, R.K. Breast Cancer Cell-Neutrophil Interactions Enhance Neutrophil Survival and Pro-Tumorigenic Activities. Cancers 2020, 12, 2884. [CrossRef] [PubMed]

143. Soto-Perez-de-Celis, E.; Chavarri-Guerra, Y.; Leon-Rodriguez, E.; Gamboa-Dominguez, A. Tumor-Associated Neutrophils in Breast Cancer Subtypes. Asian Pac. J. Cancer Prev. 2017, 18, 2689-2693. [CrossRef] [PubMed]

144. Gago-Dominguez, M.; Matabuena, M.; Redondo, C.M.; Patel, S.P.; Carracedo, A.; Ponte, S.M.; Martínez, M.E.; Castelao, J.E. Neutrophil to lymphocyte ratio and breast cancer risk: Analysis by subtype and potential interactions. Sci. Rep. 2020, 10, 13203. [CrossRef] [PubMed]

145. Palucka, K.; Coussens, L.M.; O’Shaughnessy, J. Dendritic cells, inflammation, and breast cancer. Cancer J. 2013, $19,511-516$. [CrossRef]

146. da Cunha, A.; Michelin, M.A.; Murta, E.F. Pattern response of dendritic cells in the tumor microenvironment and breast cancer. World J. Clin. Oncol. 2014, 5, 495-502. [CrossRef] [PubMed]

147. Michea, P.; Noël, F.; Zakine, E.; Czerwinska, U.; Sirven, P.; Abouzid, O.; Goudot, C.; Scholer-Dahirel, A.; Vincent-Salomon, A.; Reyal, F.; et al. Adjustment of dendritic cells to the breast-cancer microenvironment is subset specific. Nat. Immunol. 2018, 19, 885-897. [CrossRef]

148. Lenahan, C.; Avigan, D. Dendritic cell defects in patients with cancer: Mechanisms and significance. Breast Cancer Res. 2006, 8, 101. [CrossRef] [PubMed]

149. Brockwell, N.K.; Rautela, J.; Owen, K.L.; Gearing, L.J.; Deb, S.; Harvey, K.; Spurling, A.; Zanker, D.; Chan, C.L.; Cumming, H.E.; et al. Tumor inherent interferon regulators as biomarkers of long-term chemotherapeutic response in TNBC. NPJ Precis. Oncol. 2019, 3, 21. [CrossRef]

150. Savas, P.; Virassamy, B.; Ye, C.; Salim, A.; Mintoff, C.P.; Caramia, F.; Salgado, R.; Byrne, D.J.; Teo, Z.L.; Dushyanthen, S.; et al. Single-cell profiling of breast cancer T cells reveals a tissue-resident memory subset associated with improved prognosis. Nat. Med. 2018, 24, 986-993. [CrossRef]

151. Fuertes, M.B.; Kacha, A.K.; Kline, J.; Woo, S.R.; Kranz, D.M.; Murphy, K.M.; Gajewski, T.F. Host type I IFN signals are required for antitumor CD8+ T cell responses through CD8\{alpha\}+ dendritic cells. J. Exp. Med. 2011, 208, 2005-2016. [CrossRef] [PubMed] 